Florida International University FIU Digital Commons

\title{
Deconstructing the Religious Archive and its Secular Component and its Relationship to Violence
}

Andres A. Arrazola

Florida International University, aarra001@fiu.edu

DOI: $10.25148 /$ etd.FI11090101

Follow this and additional works at: https://digitalcommons.fiu.edu/etd

\section{Recommended Citation}

Arrazola, Andres A., "Deconstructing the Religious Archive and its Secular Component and its Relationship to Violence" (2011). FIU Electronic Theses and Dissertations. 472.

https://digitalcommons.fiu.edu/etd/472 


\section{FLORIDA INTERNATIONAL UNIVERSITY}

Miami, Florida

\section{DECONSTRUCTING THE RELIGIOUS ARCHIVE AND ITS SECULAR COMPONENT AND ITS RELATIONSHIP TO VIOLENCE}

A thesis submitted in partial fulfillment of the requirements for the

degree of

MASTER OF ARTS

in

Religious Studies

by

Andres Arrazola

2011 
To: Dean Kenneth Furton

College of Arts and Sciences

This thesis, written by Andres Arrazola, and entitled Deconstructing the Religious Archive and Its Secular Component and Its Relationship to Violence, having been approved in respect to style and intellectual content, is referred to you for judgment.

We have read this thesis and recommend that it be approved.

Lesley Northup

Erik Larson

Whitney Bauman, Major Professor

Date of Defense: May 5, 2011

The thesis of Andres Arrazola is approved.

\begin{tabular}{r}
\hline $\begin{array}{c}\text { Dean Kenneth Furton } \\
\text { College of Arts and Sciences }\end{array}$ \\
\hline Interim Dean Kevin O'Shea \\
University Graduate School
\end{tabular}

Florida International University, 2011 


\section{TABLE OF CONTENTS}

CHAPTER

PAGE

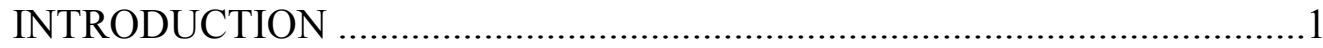

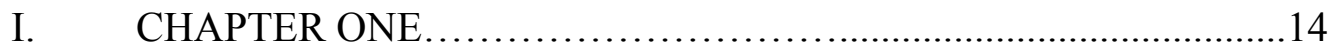

Introduction.....................................................

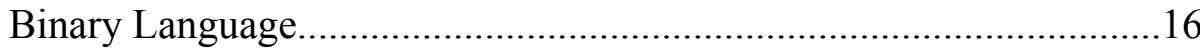

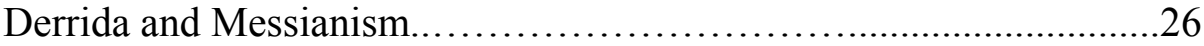

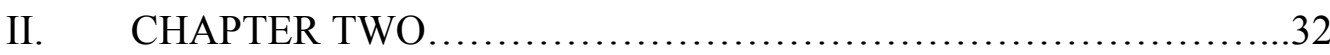

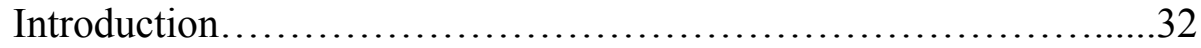

The Religious and The Secular in Riesebrodt's Method....................34

Religious and Secular from a Discursive Perspective....................47

III. CHAPTER THREE ..................................................60

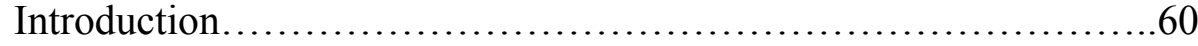

Religious Illiteracy and Kyriarchy.................................65

5 Reasons for Religious Studies...................................... 73

Conclusion........................................................ 82

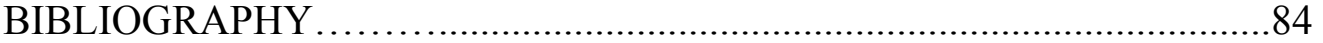




\section{INTRODUCTION}

Etymologically the word religion comes from Latin and there are two possible original definitions to the term; relegere - to pick out again, to harvest, or to read again, and religare - to bind back. Both possible etymologies connote a sense of authority since either in the practice of reading or harvesting the person is engaging dictating its own terms. There is also a sense of the other embedded in the term religion in the prefix re, indicating a sense of movement in the word that implies a returning to something and thus necessarily offering some sort of resistance. Whatever is being sought after has the affect of bonding and binding together the disparate elements within the term as well as a bearing fruit for some future moment, and when layered with cultured symbols, myths, and rituals, the process generates religious societies and traditions which are then archived into the term. So the term religion synthesizes complex and disparate processes to facilitate the understanding of the meaning making practices and traditions of societies and individuals.

The backgrounding of complexity by the logocentric deduction of such epistemic technologies grounds Derrida's claim, "To think religion is to think Roman." Derrida's statement betrays the very cultural context through which religious/secular discourse evolved in the West, namely Christian Europe. The assumptions behind the definitions of these terms are themselves culturally situated. The ideas and narratives of the secular emerge from a Western, Christian tradition, rather than as from some logical extension of replacing faith with reason as the justification for government. The narratives of the secular and the religious are further backgrounded by the "privatization" of religion under the banner of a secular public space. The "privatization" of religion has facilitated an

\footnotetext{
${ }^{1}$ Derrida 1996, pg. 4
} 
uncritical assessment of many of the underlying assumptions operating within our "secular" society, since they are generated through a Christian discourse and history.

A specific, Western understanding of "religion" leads to the idea of an a priori separation between such spaces as a private religious space and a public secular space, housing the binary division within a Western construct. The globalization of this understanding of "religion" under the guise of secularism is actually a source of conceptual (and even actual) violence toward religious others, which would be those without such a split, because not all meaning-making practices are divided into such neat spaces. The study of religion will help us to think critically about the secular/religious split and to ameliorate this conceptual violence by bringing to light the underlying complexity of logocentric technologies at work in the western construct of "religion". My thesis challenges the notion that there can be a secular space which is free from the influence of religion, as well as a religion which is free of the secular. Further, such simple separations of religious and secular leaves important biases uncriticized. These biases are carried over and operate behind the consciousness of a nation's citizens. The issue is exacerbated in a globalizing world, where the western distinction is imposed upon other spaces. It is for this reason that some form of religious studies ought to be taught in the public school system. A good place to analyze such assumptions is the public school, where students learn critical thinking skills to challenge uncriticized assumptions. The inability to ask critical questions about religion helps underwrite the religious illiteracy of the country.

To make this argument, my thesis starts by pointing to the fact that such spaces as religious or secular spaces are discursively formed rather than empirically given. The 
fact that both spaces are formulated against one another complicates simplistic attempts to define the secular, such as the secular being the public square, completely detached from a private religious space and therefore uninterested and immune from religious affairs. The significance of the discursive process which formulates secular and religious spaces, relative to their local environment, lies not only in the fact that these spaces function differently and have different characteristics in different times and in different places, or that the secular is more than simply the non-religious aspect of a society, but that both spaces are arbitrarily negotiated within their specific cultural context against one another. The arbitration process betrays the fact that both "secular" and "religious" discourses share common interests and goals, make claims on the bodies and symbols which inhabit these spaces and identify with them, and follow similar patterns to achieve these ends because the understanding of what both the "secular" and "religious" typically mean in such discourses have been constructed co-dependently. Talal Asad, for instance, comments on the similar objectives and interests among these competing discourses by localizing the discussion within modern Egypt between secularist and Islamist politicians, who are negotiating the boundaries surrounding and delineating secular and religious spaces within their local context. He writes,

Both of them agree that the rural and urban lower classes are immersed in 'non-Islamic beliefs and practices,' in a deep-rooted culture that owes more to Pharaonic and Coptic Egypt...Both agree also that these classes need to be educated out of their superstition, an obstacle to their becoming 'truly modern.'... Of course the two tendencies are by no means the same; they do not draw on the same sensibilities. Each attaches to itself elements of what is generally represented in political discourse as 'the secular' but not entirely the same elements. ${ }^{2}$

\footnotetext{
${ }^{2}$ Asad 2003, pg. 253 - 254
} 
The implications of these processes are not limited to Egypt. To tout Western secular society, as many multinational institutions do for example, as "objective and rationally based" and therefore the model of secularity to be followed across the world, backgrounds the history and politics which negotiated the construction of the American secular space vis-a-vis its religious counterpart. Moreover, to ignore the discursive processes at work behind the formations of these spaces necessarily occludes the pretext that generated the discourse in the first place. The occlusions absorb these pretexts as uncriticized assumptions within these spaces and then are spread institutionally across the world through the power incorporated by institutions' who present themselves as secular, rational, and objective, but operate on assumptions drawn from a certain history. Leaving this process uncriticized and expropriating it through government and non-government backed institutions then is to artificially impose the terms of these negotiated spaces upon other cultures when interacting with them; it is, thus, to impose the American social contract upon other societies. To emphasize the delicacy of the formation of these spaces and foster greater awareness to the processes behind them, Asad comments, "A secular state is not one characterized by religious indifference, or rational ethics - or political toleration. It is a complex arrangement of legal reasoning, moral practice, and political authority. This arrangement is not the simple outcome of the struggle of secular reason against the despotism of religious authority."3

The issue of having a critically engaged social body will be dealt with throughout the thesis and will draw on the various works of Michel Foucault. His discursive methodology and critical analysis theories neither essentializes these concepts nor

\footnotetext{
${ }^{3}$ Ibid, pg. 255
} 
empties them of substance. Instead, Foucault illustrates the processes behind the formation of concepts with his theory of "systems of formations," which emphasizes a level of sensitivity to the locality and temporality of the conditions of the formation of a concept. These conditions are generating not only the "legitimate" authorities behind the construction of a concept, but also the interactive environment which is integral to these concepts. "What are described as 'systems of formations' do not constitute the terminal stage of discourse, if by that one means the texts (or words) as they appear, with their vocabulary, syntax, logical structure, or rhetorical organization. Analysis remains anterior to this manifest level, which is that of the completed construction... in short, it leaves the final placing of the text in dotted outline." ${ }^{.4}$ When Foucault states that "analysis remains anterior" to the manifestation of an object, he is emphasizing that the formation of any object of discussion is preceded by an analysis of the constituent parts to the object. In other words, before I can point my finger at someone and say that she is practicing religion, I need to have an archive drawn that defines that activity as religious, and the audience to whom I am referring must share it as well for it to be sensible as intended by me. However, these archives are locally and environmentally situated, and when the bodies carrying the archives leave the bounds of their environment, the implementation of that archive in a different setting may generate a violent response from certain aspects of the environment. Additionally, Foucault's theoretical approach leaves concepts and their phenomenal representations, such as institutions, open ended for the reformation of these concepts from multiple perspectives. Such an approach opens up the possibilities not only to reinterpret our own assumptions about the future and the trajectories that are leading them there, but also for liberating an interpretation of the past against the

\footnotetext{
${ }^{4}$ Foucault 1972, pg. 75
} 
differing context of the present. Maintaining a cleavage between the "religious" and "not-religious" entails a passive right to the use of violence, which demands an ability to responsibility enforce it, while the violence engendered by a misrepresentation of religion is a consequence of religious illiteracy and both serve as good reasons why a religious literate population is important for social cohesion.

Secular societies such as the United States are largely ignorant to the complexity of the processes that form religious and secular spaces because of the various linguistic technologies which obscure that complexity. For various motivations, authorities within secular societies have typically resorted to simplistic and problematic definitions of secular and religious spaces to clearly demarcate the responsibilities and oversights of the two. A typical definition of "secularity" suggests discourse grounded in reason and a disenchanted view of the world. The construction of such a space is "cleanly" demarcated appositionally, in a binary relationship, to a religious discourse grounded in belief in "superhuman/supernatural" powers with a voluntary "faith-based" membership to its institutions. The self-understanding of the secular as institutionally separate from the religion based on a relationship to "superhuman powers," when left uncriticized, can easily justify an understanding of the position of the secular as "above" the religious in terms of authority and "objectivity," since access to it is assumed to be universally available rather than through faith-based assent. Such a conclusion also implicates the religious as not being concerned with the day to day worldly affairs everyone shares, but rather with the "spiritual" or God, etc. The other implication for religion in this definition, since it derives the authority of its claims from a "metaphysic," is that it needs 
to be scrutinized and criticized before it is accepted in a way that acceptance of secular assumptions is not.

A rigid, binary institutional approach to defining the secular and the religious backgrounds how and when religion is acting within an institutionally secular space and when the secular is acting within a religious space. The biggest issue with a dogmatic institutional approach to conceptualizing religious and secular spaces is that such rigid categorization violently suffocates attempts to reform these spaces. Not only does this method radically exclude religious sources of knowledge and backgrounds the genealogical process by which we have contracted the porous limits of our own negotiated secular and religious epistemology, but implicit also is the assumption that secularity is the eventual developmental goal of modernity. The problem with projecting secularity as the eventual telos of modern development becomes more acute when a particular brand of secularity, such as American style secularity, is being spread across the world through various secular institutional mechanisms such as the World Bank and the IMF, operating under the guise of "rational and objective social scientists." In this process, what gets left behind in the presumptions of our present "modernizing projects" is that these institutions carry with them, not only economic models of development, but a certain ethic and lifestyle that are structured by the "modern project." They in turn become imposed, through the various institutional mechanisms, upon those in other societies just as in previous times the colonization of "new worlds" and Christianizing of peoples took place under the guise of progress.

But what evidence is there that there is such a thing as 'a modern project'?...Especially over the past fifteen years, the analyses and prescriptions by international agencies dominated by the United States 
(OECD, IMF, the World Bank) have been remarkably similar regardless of the country being considered...As Halimi notes, that model is not confined to matters of free trade and private enterprise but includes moral and political dimensions-prominent among them being the doctrine of secularism. ${ }^{5}$

What is revealed, if these dimensions are deconstructed even further, is not only Western styled secularism uncritically imposed via its representative institutions, but also the pretextual assumptions which allow for this particular conceptualization of secularism and its contingent institutions to arise, such as the very religion/secular divide and the assumptions that feed it. When these doctrines are contextualized within an epistemic framework which understands and defines the religious/secular divide as binarily and irreconcilably opposed to each other, and moreover, one that marginalizes religion as inherently inconsequential to worldly affairs, this conclusion will generate conflict. Mark Juergensmeyer in Terror in the Mind of God has demonstrated how recent cultures of religious violence developed when faced with this "modern project" and the satanizing discourse they implement to justify their behavior. One unitive element tying the discourses on the conflict between the interests of global financial institutions and the lifestyles they structure in other societies is that they receive their justification and support through the citizenry of secular Western states. They therefore are encumbered with the responsibility of recognizing the consequences of the actions of those who speak in their name.

One assumption perpetuated by the "modern project" derived from Western thought, relevant to the formation of religious cultures of violence, is the hyperaccentuation of the conceptualization of agency as individual and active while veiling

\footnotetext{
${ }^{5}$ Asad 2003, pg. 14 - 15
} 
other forms of agency. The approach to agency being illustrated backgrounds the genealogical relationships between the effects of an act upon the environment, especially as the event becomes spatially and temporally distant. This is to say that religious cultures of violence are part and parcel to the discourse they are critiquing, because it is that discourse which helps to generate the formation of such cultures of violence. When Western media pundits demonize religious cultures of violence as solely responsible for religious acts of violence, they absolve themselves and Western society of their responsibility for acts of religious violence. Ultimately, such conceptualizations of agency reduce the recognition of the value placed on the surrounding environment as a formative aspect of relationships, as well as the individual's and society's role as an environmental factor. The surrounding environment then is seen as purely instrumental. The silencing of the environment as formative and value-laden reinforces a buffered sense of identity that is carried over into institutional identities, such as a "buffered" secular space and a "buffered" religious space. This repression of variant forms of agency is at least in part a symptom of religious illiteracy within the U.S. citizenry, which awards agency to the individual, active and proximate agent of an event and is reluctant to value passivity as a form agency. A buffered sense of identity, coupled with radically reduced sense of responsibility, justifies the dissemination of the West's own understanding of right action globally and uncritically by its citizenry, because they are freed from the guilt that would arise if they were to recognize their connection to a religious act of violence. Mind you, this sense of self-righteousness and innocence is then coupled and propelled by the belief that Western ideology equates with rational objectivity. The moral and political dimensions referred to by Asad in the above passage 
become especially volatile when they are universalized and reinforced with state apparatuses, such as the judicial system, the monetary institutions, and military institutions of the "modern project."

To reconcile the differences that result when opposing worldviews collide, judicial systems are charged in modern, secular states with maintaining social cohesion and peace through the use of legitimized violence. But these judicial institutions are themselves encoded with certain cultural assumptions since they demand to be the only legitimate source of violence within the bounds of a society. This assumption necessitates a delegitimization of other forms of violence including religiously legitimized forms of violence within societies. Also, these judicial mechanisms often fail when applied to other environments, regardless of their "objectivity." One such foundational assumption is that citizens of secular states are universally subjected to the judicial process because of the value of universal human rights guaranteed by secular states. The usage of universalizing language to justify Western institutions within Western societies becomes the basis for justifying the same institutions elsewhere. The stress that arises from the arbitrary implementation, through the mechanisms hinted at in the previous paragraph, of culturally constructed understandings of the prescribed role of religious/secular spaces has a direct connection with the question of who administers the legitimate use of violence within a society. This has become an acute problem with our rapidly narrowing world; therefore, the third reason this thesis argues for the inclusion of religious studies in a public academic setting is to equip students with a deeper understanding of the connection between religion, violence, and their cultural constructions. When the judicial system of a society finds difficulty reconciling itself as the only legitimate authority to 
dispense violence within a society, as is the case with vibrant cultures of religious violence, the use of violence spills out from the judicial parameters, and thus acts of terrorism arise. The study of religion helps to alleviate some of these issues by giving the public the tools to criticize and reform the differing elements of their society and how they approach other ones as well. Not only is the study of religion relevant for an understanding of the mechanisms of our own judicial system, but it also gives a deeper understanding to why religious "fundamentalists" resort to terrorism and equips American citizens with tools to better critique government policies constructed around the political manipulation of terrorism. This is not to mention that these students become the next generation of soldiers who are charged with the primary responsibility of mitigating the danger of religious violence, but they also, most probably, become the first experience of an American when they are stationed in countries such as Iraq or Afghanistan. After studying this process, what is enlightening is the fact that the religious "fundamentalists" are portrayed as "socially deviant" others, who then bear the full brunt of judicial violence and, paradoxically, have to be demonized and stripped of their universal humanity. The stripping of these rights is in order to justify the judicial violence that social deviants receive against their embodied dignity as human beings, in other words, the rights "endowed by their creator" must be compromised. The internal conflict within the social psyche between the construction of the "ideal" person, who can fully exercise and is worthy of the grace of human rights, against the justification for removing them from the social deviant, can be seen in the following passage from Asad. His comment on the dissonance that arises for the justifications that validate the 
conceptualization of universal human rights is crucial for understanding how the judiciary justifies the dispensation of violence towards its social deviants.

[Hanna]Arendt might have noted, however, that sacredness in the modern secular state is attributed not to real living persons but precisely to the 'the human' conceptualized abstractly, or imagined in a state of nature. Every real person who belongs to a particular nation-state is always subject to its intuitional violence-including the violence of its law, and liable to military conscription that can result in his death. It is only the abstract modern citizen who is sacred by virtue of his or her abstract participation in popular sovereignty. ${ }^{6}$

The enlightening aspect is that in truth then, no person can truly live up to the universalized image of a prototypical person, and it puts those who perpetuate these types of assumptions into a difficult position, since their own hypocrisy could easily become unmasked. The implications of this hypocrisy are realized both in the state and the individual. Not only are individuals not able to fully live this abstract standard of personhood, but these individuals make up the state itself. The inconsistency between the promotion of Western secularization and its corresponding notion of "individual" and universal human rights as inevitable and indemnified from critique is what creates dissonance both within and around this model of secularity. This is true, not only of religious "fundamentalists" but also with all socially deviant aspects of society, which in various periods of our social history, have had to bear this violence. With respect to other societies, Talal Asad demonstrates that the imposition of the common assumptions of a secular state have ruptured the social fabric of Islamic countries when complicated with issues of nationalism, religion, identity, authority, and judicial procedure.

Thus for secularists each citizen is equal to every other, an equal legal and political member that itself claims a single personality. In their

\footnotetext{
${ }^{6}$ Ibid, pg. 143 - 144
} 
scheme the categories 'majority' and 'minority' technically relate to electoral politics only, but in practice they reflect entrenched social inequalities. For Islamists they are basic cultural categories that define citizens as necessarily unequal. In the modern state, both make it difficult, if not impossible, for people who belong to different religions (Muslims, Christians, and Jews) to live in accordance with their traditions without - on the one hand - having to be grouped invidiously as dhimmis (non-Muslim protected subjects of a Muslim state) or - on the other hand - as 'ethnicities' (that is, as 'minorities' unwilling or unable to assimilate to 'the national culture'). ${ }^{7}$

The final chapter of my thesis will focus on how the teaching about religion provides access to differing conceptualizations of all of our assumptions, and how they function in a given time and place. Critiquing the pretextual assumptions of a society gives students the opportunity, in concert with the other critical tools developed throughout the curriculum, to criticize and articulate how they wish to be represented. Moreover, the teaching about religion gives students multiple examples of how different religious people practice their faith, thereby rupturing stereotyped misrepresentations and alleviating the consequences of demonization. This brings me to the last and perhaps most important point of the thesis, the teaching about religion within a public school setting will help create an attitude of self-criticism that unearths the assumptions of society; such unearthing is ever more important in a globalized world if we are to avoid conceptual and actual violence based upon background definitions within our most closely held assumptions.

\footnotetext{
${ }^{7}$ Ibid, pg. 250
} 


\section{CHAPTER ONE}

\section{INTRODUCTION}

As I argued in the introduction, simplistic approaches to defining what is "religious" and "secular" helps to promote religious violence. In what follows, I examine this violence in terms of what Juergensmeyer describes as a process of "satanization." This chapter will argue that the underlying linguistic structure of Juergensmeyer's term "satanization" is a form of binary language that seeks to place the blame upon an other for all the perceived social ills. Satanization is structurally related to the process by which the hard secular/religious divide arises. In its satanizing form, binary language justifies the specific use of religious violence toward others in an effort to alleviate their social ills. Religious violence is justified by dehumanizing the opponent and conferring upon the other the role of the absolute category of the "demon" with respect to what Juergensmeyer has termed the "cosmic war" scenario. In the case of the problematic secular/religious divide, the United States government and society is typically represented as the prime bastion of secular society and its progenitor across the world. The association of American society as the exemplary social model leads the United States government to be portrayed as the "demon" in these "cosmic war" scenarios. "More than any other nation, America has been assigned the role of primary or secondary foe." ${ }^{8}$ As such, it is criticized not only by radicals outside of the United States, but also by radicals within the United States who are critical of it. The satanizing process is present in the Christian anti-abortion activist Michael Bray's characterization of the American government as, "Nazism and advocating a biblically based religious politics to

\footnotetext{
${ }^{8}$ Ibid, pg. 181
} 
replace the secular government." ${ }^{\prime 9}$ Juergensmeyer agrees with the typical depiction of the United States as supporting secular values and capitalist structures. "Like all stereotypes, each of these characterizations holds a certain amount of truth. America's culture and economy have dominated societies around the world in ways that have caused concern to protectors of local societies." ${ }^{, 10}$ Ultimately, any proposal to address religious violence has to consider not only the backgrounding of the role of religious principles in secular societies, but also the material conditions, poverty, health care, etc., and the linguistic mechanisms such as satanizing and essentializing languages which justify violent behavior. The ignoring of religious language in the secular is precisely part of the reason that the secular society of the US can be satanized: in claiming some sort of universal reason accessible to all, it is an affront to the truths of religious peoples.

Returning to the relationship between violence and the maintenance of the secular space, we are caught in an almost aporic situation; on the one hand the differentiation of secular politics from religious institutions is what enabled secular values to flourish, but at the same time has encouraged a violent response from fringe but important religious groups, which threatens them. Here we should be able to see why rigid institution approaches to religious and secular spaces engender violence. One cannot do without the other, and when the other is silenced and backgrounded, they retaliate aggressively. To relieve the tension, secular society needs to re-empower religion and religious groups but in such a manner that does not jeopardize secular-minded people. On the other hand, to reintegrate religion and religious institutions' to positions of power within a secular

\footnotetext{
${ }^{9}$ Ibid, pg. 27

${ }^{10}$ Ibid, pg. 184 - 185
} 
environment, their totalizing and at times mutually exclusive discourses would need to be diverted from their claims upon the bodies of religious and non-religious people. In other words, religion and their representatives would need to find a place within the secular space where they are neither silenced, nor so loud that they hinder their adherents from acting on their own conscience. The hope is that both parties recognize their mutual existential (and historical) co-dependence, and for both to recognize they are making differentiating claims on the same bodies, which leads to stress. Juergensmeyer comments on how the images of violence within a religious context provide the escape and rationale for the underlying sense of hopelessness. He writes, "The irony of these bloody images is that the object of faith has always been peace. But in order to portray a state of harmony convincingly, religion has had to emphasize disharmony and its ability to contain it." ${ }^{\prime 1}$ To achieve a balance to the constant portrayal of the United States as the "demon," a counter-discourse to that demonization would need to be perpetuated, thereby suggesting a furthering of binary language.

\section{BINARY LANGUAGE}

Binary language, as briefly mentioned above, constructs absolute categories in an effort to portray objects as polar opposites by manipulating signs, and generating cleavages such as: "religion/secular," "black/white," "positive/negative," "good/evil," "war/peace," “subject/object," "pure/impure," “male/female," or "us/them." When signs

\footnotetext{
${ }^{11}$ Ibid, pg. 162
} 
are formulated against each other in such a way, the categories within a binary language construct functions as a form of what Foucault calls a "statement," which he defines as:

the modality of existence proper to that group of signs: a modality that allows it to be something more than a series of traces...something more than a mere object made by a human being; a modality that allows it to be in relation with a domain of objects to prescribe a definite position to any possible subject, to be situated among other verbal performances, and to be endowed with a repeatable materiality. ${ }^{12}$

In other words, binary language is the structure in which groups of signs are articulated against each other in a mutually exclusive way. The presentation of these signs as mutually exclusive is problematic because the nature of the relationship between the signs in any language construct is fluid, while needing to maintain a relationship to each other so the association to their referent can be sensible. The consequence is that the actual relationship between the signs can be modified into something else, disrupting the clarity of representing that to which the signs refers, but at the same time liberating the signs from always representing the same referent. What makes binary language distinct to other forms of statements is the value it applies to the positions of the signs constructed by the statement, as well as presenting the signs in such a manner that the categories appear fixed in time.

Oppositional binary language qualifies one aspect of the statement over the other by silencing the other of the two and denying their mutual dependence. The silencing of the other creates a monological understanding of the signs/value system, which leads to the essentialization of the objects signified according to the demands of the first position. Val Plumwood has a similar critique of binary language, which she refers to as radical

\footnotetext{
${ }^{12}$ Foucault 1976, pg. 107
} 
dualism, which is a binary relationship that refuses to admit their interrelatedness. She writes, "Dualistic constructions of reason and nature, mind and body, spirit and flesh create polarizing metaphors and understandings of these elements which are woven through many kinds of social division in the dominant culture."13 To essentialize the categories presented, there needs to be a mechanism which qualifies and justifies the signs against each other. Plumwood summarizes an example of the judicial process of valuing one pole of the statement over the other with respect to the binary construct of reason/emotion compounded upon the male/female construct. She writes, "Reason, the 'manly' element in the soul, was opposed to the inferior and corrupting 'female' elements...Reason in the human was lodged in the higher body and especially the head... and in the case of the larger world the seat of reason and value is in a timeless abstract higher realm." 14 The gendered representation of the "public" space as "masculine" and "rational" against the "private" space as "feminine" places greater value to the public/masculine/rational paradigm over the private/feminine/emotional paradigm, and reinforces the static binary division of religion/secular. Religion becomes implicated in this process as it is represented as feminine when it is pushed, at least perceptionally, to the "private" space. The religion/feminine/private mix becomes especially dangerous when men in marginalized cultures of religious violence have understood their religion to be emasculated, and take arms to remedy this. Juergensmeyer comments to this as well,

These fears of impending marginality have undoubtedly helped to fuel the racism of many radical religious movements. Kerry Noble, one of the leaders of the Christian Identity...said that he used to preach

\footnotetext{
${ }^{13}$ Plumwood, pg. 19

${ }^{14}$ Ibid, pg. 20
} 
sermons describing blacks as the "beasts of the field"...blaming Jews for most of the problems in the modern world: "for the pornography, for the lack of morality, for the economic situation in America, for minority rights over white rights, and for kicking God out of the schools."...Noble was expressing his own frustration over the inability of white Christian men like himself to control the world around them. ${ }^{15}$

With their static representations and "qualified justifications," the categories mentioned above go uncriticized and draw a myth of eternality to them, i.e. they are taken as "common sense." One such binarily constructed myth revolves around the hyperseparation of humans from the natural environment, or anthropocentrism. Leaving the myth uncriticized as it is in our society perpetuates a sense of alienation from the environment within the consciousness of those under the spell of anthropocentrism. The sense of alienation is then reinforced through various technologies such as the construction of another myth that places humans at the center of creation, charged with the responsibility to steward if not outright dominate the rest of nature. The ubiquity of the developed sense of alienation is also present as a part of the secular, scientific narrative, which allows scientists to experiment on dead nature; and allows consumers to consume raw materials uncritically from the rest of the natural world. To achieve the effect of eternality, what binary language has to background is its modal elements, meaning the different dimensions within the statement that can also be rearranged to highlight different aspects and other dimensions to their reality, thus revealing different qualities, conclusions, and relationships. To justify the myth of anthropocentrism it has to be presented as if it is a revelation from God, or a reflection of some external dimension that is the "really real," if it is to obstruct this modal reality. The occlusion of its modality supports the primary end of binary language constructs, which is to produce

\footnotetext{
${ }^{15}$ Juergensmeyer, pg. 195 - 196
} 
some qualified object over another, and present it as knowledge that is justified because can be repeatedly verified. Such knowledge can then be used for manipulating the material objects for the purposes of the primary pole by closing off alternate possibilities of becoming. Once again we turn to Plumwood for an explanation of the relationship between the knowledge produced and justified by a binary relationship. "As we have seen, knowledge, instead of being a collaborative effort between knower and known, in part the creation of a nature conceived as rationally knowable, is reconceived as entirely the creation of a rational (male) knower who monopolizes agency and reason." ${ }^{\text {16 }}$ Plumwood also eloquently verbalizes the result of the implementation of binary language constructs when she writes,

A sharp boundary and maximum separation of identity enable the beneficiaries of these arrangements to both justify and reassure themselves...Typically supremacist classifications reconstruct a highly diverse field in which there may be many forms of continuity in terms of two polarised and internally homogenized 'superior' and 'inferior' racialised or genderised classes. ${ }^{17}$

To rupture the static representation of objects enabled by binary language and the limited knowledge produced through its framework, I analyze the discursive elements which allow their construction. Such an analysis is important for the religious/secular divide because it is the tool through which assumptions such as anthropocentrism, or the feminization of the private space and its association with religious spaces, can be sifted, and hence deconstructed and analyzed. First, for the categories in a binary language construct to oppose each other there needs to be a discourse which sets one against the other, such as the discourse which places religion as the "private" aspect of a society

\footnotetext{
${ }^{16}$ Ibid, pg. 49

${ }^{17}$ Ibid, pg. 102
} 
against the "public" secular aspect. The discourse itself is bound by the context surrounding the author of a statement, which localizes and materializes the statement.

Foucault states, "To describe a statement is not a matter of isolating and characterizing a horizontal segment; but of defining the conditions in which the function that gave a series of signs... an existence, and a specific existence, can operate." ${ }^{, 18}$ With respect to satanizing discourses, religious language and imagery are always drawn from a particular religious tradition, and not only a singular religious tradition such as Islam per se, but Islam as understood in its violent context. "Discourse in this sense is not an ideal timeless form that also possess a history... it is, from beginning to end, historical - a fragment of history, a unity and discontinuity in history itself, posing the problem of its own limits." ${ }^{\text {19 }}$ Second, since discourses have a temporal and historical grounding to them, it is the context of a discourse that becomes the generative source of significance for the objects in a binary language construct because it is what formulates the differences between the categories. Importantly, the context of one discourse can also be part of another discourse, and not all the texts of a discourse are necessarily to be found in every other discourse. The implication of closing off access to the texts of other discourses, or how the same text can be understood in a different discourse, is a brushing aside of notions of relationality and replacing it with some vague ideological constructs, such as a "guiding spirit," "development," or "continuity." Such constructs however insidiously unify statements and events within a discourse. Instead the bond of the binary

\footnotetext{
${ }^{18}$ Foucault 1976, pg. 108

${ }^{19}$ Ibid, pg. 117
} 
is not seen as relative and relationality is backgrounded, thus closing off possibilities for recreation.

Relations between statements (even if the author is unaware of them; even if the statements do not have the same author; even if the authors were unaware of each other's existence); relations between groups of status thus established (even if these groups do not concern the same, or even adjacent, fields; even if they do not possess the same formal level; even if they are not the locus of assignable exchanges); relations between statements and groups of statements...To reveal in all its purity the space in which discursive events are deployed...is to leave oneself free to describe the relations within it and outside it. ${ }^{20}$

Discourses are dependent upon other discourses, each generating their own respective, tentative, and sometimes antagonistic historical trajectories. The interdependency of discourses means that within a discursive formation there is always an "other" against which other discourses are able to form objects, concepts, and strategies, binding discourses together. The other's response to a discourse is the fruit of the call and response game in which statements are made into an unknown future and await a response (an affirmation or a denial). Whenever a statement is set into a discursive formation, the audience can hear in the silence, as they await the response, the culminated historical trajectories of a statement within a discursive formation, but this takes deconstruction. The tenuous relationship between the formation of objects, our groping for their verification, and the stability they provide is succinctly stated by Derrida, in terms of the arkheion., "The arkheion of which we are the guests, in which we speak, from which we speak. To which we speak, I might also say: addressing it. ${ }^{, 21}$ It is the initial experience of the arkheion, the moment of the unitive bond between an object

\footnotetext{
${ }^{20}$ Ibid, pg. 29

${ }^{21}$ Derrida 1998, pg. 20
} 
and the meaning ascribed to it by the witness that everyday speech attempts to reproduce when communicating. To speak in the arkheion is effectively to mean what one says about whatever one is saying, while at the same time and in that very process, addressing whatever has already been said about the elements represented. Speaking plainly about something, or witnessing and sharing to an arkheion initiates two functions that enable the two poles of a binary relationship, a sequential function and a jussive function. "We have there [the arkheion] two orders of order: sequential and jussive. From this point on, a series of cleavages will incessantly divide every atom of our lexicon."22 The jussive function of the arkheion gives the relationship its voice so to speak, its characteristics against which representations of that relationship are then judged. The jussive function gives speech its plainness. The importance of the jussive function is that it sets the initial boundary that forms the way relationships are then represented, and makes these representations matter because they are documented and stored in the memory, not only of those represented but in those witnessing to the representation. Moreover, that first impression leaves the witness with an image that becomes a burden to overcome for the object being represented should there arise a need or desire to do so. These representations are carried in the consciousness of those involved in witnessing the representation, initiating the sequential function of the arkheion, which, alongside the jussive function of other arkheions, the elements that give rise to the arkheion are repeatedly judged, thus bifurcating each element. Representations then are never neutral; they always carry with them some subsequent implication and are necessarily presented as true for them to be credible and useful, which also implies a struggle to overcome a

\footnotetext{
${ }^{22}$ Ibid, pg. 1
} 
misrepresentation. The accumulation of these representations and misrepresentations is catalogued in an archive.

There is a second component to Derrida's conceptualization of the arkheion which is critical for this thesis, and that is that the arkheion is also a place. "There, we said, and in this place. How are we to think of there? And this taking place or this having a place of the arkhe?" There are two aspects to the place of an arkheion, the "taking place" and the "having a place." My thesis understands that the "taking place" of an arkheion, the bonding of a certain representation of the other to me, to be spontaneous bonds that can occur any moment or at any time, through casual conversation, eaves dropping off-handed remarks, uncriticized presumptions, images in motion, etc. The "having a place" refers to sites which are looked upon by society to construct such bonds, such as the public school, a body, landscapes, written words, etc. These two aspects are not mutually exclusive and both rely on each other. For the "taking place" to flourish, it seeks the protection of the "having a place." And the end of "having a place," is for construction to "take place." The public school as a "having a place" for building bonds will be dealt with in greater detail in the next chapter, as this chapter will continue to focus with the "taking place" aspect of archiving. So, for the moment it is sufficient to note both aspects of place with the arkheion and move on to the implications for binary constructs.

Alongside the bond between signs in a statement there is an empty space that allows for the dispersion and redistribution of statements. This allows for differing discursive formations to develop. Foucault explains that, "the 'signifying' structure of language (langage) always refers back to something else...Language always seems to be 
inhabited by the other, the elsewhere, the distance; it is hollowed by absence. ${ }^{, 23}$ Binary language is one formation that erupts from this space on account of its drive to essentialize its categories. Binary language fills the void between the poles of a statement with an unbridgeable distance rather than a discursive void. Such a void allows for the cleavage of sequential time, disrupting misrepresentations and their sequential and jussive trajectories, and the closing up of this space is a further affront to relationality. The suppression of the empty space is critical for the binary language construct Val Plumwood labels "hegemonic centrism," which she describes as, "a primary-secondary pattern of attribution that sets up one term 'the One' as primary or as centre and defines marginal Others as secondary or derivative in relation to it, for example, as deficient in relations to the centre. ${ }^{.24}$ It is the re-opening of the empty space that teaching about religion can achieve: not only in regards to religious/secular distinctions, but to other discourses couched in binary terms. Examining these empty spaces reveals the relationality between others and the violence caused by ignoring this relationality.

The consequence of leaving the void between binaries, between "others," unfilled and discursive would mean leaving the void open to spontaneity and uncertainty. It is precisely this uncertainty that the filling of a void with a binary construct seeks to avoid. To reopen the space would entail a revaluation of the quality accorded to both positions in a binary construct. There is a very real effect to the secondary or peripheral pole in a

\footnotetext{
${ }^{23}$ Foucault 1976, pg. 111

${ }^{24}$ Plumwood, pg. 101, Plumwood has five aspects to her theory: radical exclusion, stereotyping/homogenisation, backgrounding/denial, incorporation, and instrumentalisation. This methodology explains how the appearance of the marginal other is presented as irreconcilable to the dominant center, all differences within the margins are whitewashed for uniformity's sake by backgrounding these differences to minimize possible connections with the center that would allude to a mutual dependency, and both margin and center are reincorporated according to the dictates and demands of the center.
} 
hegemonic centric structure: it produces a sense of humiliation and invalidation for the distanced and silenced other. The question becomes how to redirect the discourses feeding religious justifications for violence without further alienating the humiliated and downtrodden by invalidating their experiences, and without emptying the critical nature of religious spaces. To open up potential discourses, a more profound view of language and its relationship to religion will need to be investigated. The study of religion could be used as a forum for people to give voice to their dissatisfaction or grievances with secular society without resorting to violence, as well as, providing an opportunity for secular leaning students/witnesses to articulate their concerns on religious matters.

\section{DERRIDA AND MESSIANISM}

Such analysis of language must take note of what Derrida calls the messianic drive of language. Since religion seeks to discourse with that which is beyond human technologies such as archives, there can never be a complete validation to the waiting for the justification of religion's claim, i.e. objective validation of the ultimate referred to in religious practice, only a mystical validation or the true eschaton could do so if at all. To momentarily settle the issue of religion within this process a turn to Derrida's term of domiciliation serves as a good parallel:

The meaning of 'archive,'...comes to it [Latin] from the Greek arkheion, initially a house...the residence of the superior magistrates, the archons, those who commanded...On account of their publicly recognized authority, it is at their home, in that place...that official documents are filed. The archons are first of all the documents" guardians....They are also accorded the hermeneutical right and competence...to interpret the archives. Entrusted to such archons, these documents in effect speak the law: they recall the law and call on or impose the law. To be guarded thus, in the jurisdiction of this speaking the law, they needed at once a guardian and a localization. Even in their 
guardianship or their hermeneutic tradition, the archives could do neither without substrate nor without residence. It is thus, in this domiciliation, in this house arrest, that archives take place. ${ }^{25}$

So, the archive is a site of authority and the platform from which a witness testifies and enables the witness to begin to testify. "The archive stands, then, as the address that grounds all address, the place that makes way for place, the site that commands and commences. It is the address from which an individual responds, just as it is that which makes response possible, that to which everything is always responding. ${ }^{.26}$ For an archive to retain the authority it emits, it needs a place which intersects with its power to allow the domiciliation process to occur, the symbiotic relationship between the "taking place" and "having a place" of the archive. "They all have to do with this topo-nomology, with this archontic dimension of domiciliation, with this archic, in truth patriarchic, function, without which no archive would ever come into play...To shelter itself and, sheltered, to conceal itself. ${ }^{, 27}$ Each archive has its own archival starting point, which Derrida has termed the arkhe, which in a religious archive would be a revelation of the ultimate. The arkhe is what enables each testimony and to which each testimony refers back to justify. Robert elaborates on the original arkhe moment, "The arkhe marks the originary cleavage; it separates inside and outside, leading to a series of cleavages that mark here and there, now and then, thereby making possible all such conditions of difference. ${ }^{28}$ The cleaving function of the arkhe allows signs to be identified, classified, and gathered into the archive, which Derrida terms as the archontic

\footnotetext{
${ }^{25}$ Derrida 1998, pg. 2

${ }^{26}$ Robert, pg. 45

${ }^{27}$ Derrida 1998, pg. 2

${ }^{28}$ Robert, pg. 45
} 
principle. The process of the gathering together of the like signs into the archive Derrida terms consignation under the archontic principle. "Consignation aims to coordinate a single corpus, in a system or a synchrony in which all the elements articulate the unity of an ideal configuration., 29

The testimony takes place in an instant and it is not for the now per se, instead its authority will lie in the future when the moment itself lies in the past. When a present is coming from the future, it seeks to control its unpredictability with the authority of that past, as it were a 'resurrection of the dead' from the archive occurs. Now, the archive stands as a storehouse of the cleavages which hold testimonies to individual identities. The archive stores private memories turned to objects of history, which is enabled by the actions of the witness' testimony, demarcating the archive as a unique place which blurs rigid categories. "Hence the archive is the place where private (inside) and public (outside) meet. ${ }^{, 30}$ These memories are imbued with language and language is prime technology of the archive which gives direction to the future in the present with references to the past through the accumulation of witnesses. The testimonial of each witness labels, identifies, anoints, a person, place, and presence for public scrutiny. These testimonials form the first discourses that enable other discourses. The positive anointing by the witness Derrida labels as messianicity without messianism, whose spontaneous arrival creates an anxiety: "be prepared (waiting without awaiting itself) for the best as for the worse, the one never coming without opening the possibility of the

\footnotetext{
${ }^{29}$ Derrida 1998, pg.3

${ }^{30}$ Robert, pg. 45
} 
other." ${ }^{, 31}$ The source of the anxiety lies in the uncertainty of the chora as it slides from future to present, surrounding the witness and archive, and it is this anxiety to control that also propels the witness to testify. "To bear witness, then, always bears witness to death...Delivering a eulogy - testifying to the life of the other who has in some sense drowned - is the work of mourning issuing forth from the 'here I am' at the root of all testimony." 32 Robert Gibbs reiterates the futurist preoccupation of the archive propelled by a fear of death, which underlies its messianic attribute. He writes, "The archive as a preserve of past events exists for the sake of the future, and indeed, for an opening of the future. Historical research is not about the past but about the future."33 Through the housing of discourses, testimonials, statements, etc. in archives, it creates a messianic component which seeks to justify its actions in the present through a representation in a future that will never materialize as articulated because any articulation can never fully describe the future. What lies in the future that is known is death, hence the anxiety over unpredictability. This anxiety is exacerbated by the multiplicity of archives, each projecting its own messianism and anxieties over death.

This underlying anxiety is what drives William Robert's understanding of the act of witnessing: "Echoing Abraham's response to God's call in Genesis 22:1, the witness responds to a call, and in doing so, she identifies a place, a person, and a presence...This framework gets at the heart of the act of bearing witness-and it is an act, an action that she performs, for to respond, she must act." ${ }^{\prime 34}$ Moreover, the speaker is necessarily

\footnotetext{
${ }^{31}$ Derrida 1996, pg. 18

${ }^{32}$ Robert, pg. 47

${ }^{33}$ Gibbs, pg. 121

${ }^{34}$ Robert, pg. 38
} 
identified with the testimonial given. "Hence any speech act takes place because the speaking individual identifies herself with and in the very event of saying." ${ }^{35}$ Thus to bear witness is encumbered with an implied responsibility.

Not only does the witness who offers testimony promise to speak to the other (for testimony is always addressed to an other) but she also promises to speak truthfully...Bear witness, then, is a response. It stands as an individual's response to the call of responsibility and to the promises carried by that call. ${ }^{36}$

Thou shalt not lie, to lie is to break the underlying faith between audience and the witness, for a testimony is always presented as truthful. Paradoxically, the testimonial can never fully articulate whatever is being witnessed to and in a way is always a lie. The incessant anxiety of validating the faith in a witness, in verifying the testimony as fact, is reminiscent of what Derrida terms as "messianicity without messianism." "This would be the opening to the future or to the coming of the other as the advent of justice but without horizon of expectation and without prophetic prefiguration.. ${ }^{37}$ By preconceived expectation and prophetic prefiguration, Derrida speaks of a particular religious understanding of messianism, as opposed to messianism as a phenomenon of language itself. "This justice inscribes itself in advance in the promise, in the act of faith or in the appeal to faith that inhabits every act of language and every address to the other. ${ }^{, 38}$ The responsibility of the witness to the audience of her testimony, as well as the fact that this responsibility can never be fully carried out, is affected by the reality of death, which is religion's promise, and to which each religion testifies.

\footnotetext{
${ }^{35}$ Ibid, pg. 43

${ }^{36}$ Ibid, pg. 39

${ }^{37}$ Derrida 1996, pg. 17

${ }^{38}$ Ibid, pg. 18
} 
In conclusion, binary representations erupt from an environment through the experiences of those defining the terms of a binary relationship. The bond that relates to the elements to one another and defines them has to be attested and witnessed to by others, initiating a movement, in order for the bond to have a material dimension, thus forming the testimony. Through the act of witnessing and testimony, archives are formed which house the testimonies as they move through time and the archives themselves are labeled, forming a new bond and generating the archive's messianic dimension. The messianic dimension of the archive illustrates the problem of the name. Underneath the name lies shifting and fluctuating movements which dislocate the bonds of the name to their intended archives. In the crisis of dislocation, the messianic dimension of the archive also holds a promise, since these layers were materially generated, that the dislocated bond can be repaired, however unlikely the possibility for such an event to occur. The problem is present whenever speaking about the secular as apart or separate from the religious, and is exacerbated when "foreign" formulations of the same elements are introduced into the environment. In other words, the promise of the American secular society is a promise to its American religious societies, which have been predominantly Christian. Some groups of Muslims, Jews, and even other Christian groups feel they have not negotiated their positions within the same archival network, or as some of their numbers grow, would like to renegotiate the terms. The issue of violence arises when the secular then presents itself as open to a religious denominations but betrays preferences for certain religious practices, undermining its own principles. 


\section{CHAPTER TWO}

\section{INTRODUCTION}

This chapter will explore the issues involved with relying solely on simplified definitions of religious and secular spaces, such as a model based on a binary differentiation between the institutions' functions. The chapter will begin with a critical analysis of a theory of religion posited by Martin Riesebrodt, who uses such a problematic methodology derived from institutional differentiation. One issue of Riesebrodt's approach is that it backgrounds the interdependent relationship between the formulations of both religious and secular spaces and does not recognize a space that can potentially rupture such static representations should the need arise. In other words, Riesebrodt does not offer a space in his analysis that is not clearly religious or secular in order to delineate the secular from the religious, or to question spaces when they are presented as secular or religious. Setting out to define religion or the religious as Riesebrodt does, he falls directly into the binary trap articulated in chapter 1 . By focusing on the problematic use of a clear typological model based on a hard institutional demarcation between religious and secular institutions, this chapter will also argue that a discursive approach to the study of religion, which Riesebrodt absolutely abhors, is still a better approach than Riesebrodt's typology. Discursive approaches highlight and explain the dynamism behind the archives of religious traditions and their secular counterparts (as discussed in the previous chapter). Moreover, discursive and deconstructive methodologies unpack the generative mechanisms by which the differing constituent parts of a religious tradition form and disperse according to differing environmental conditions in order to form our present, localized, epistemological framework, and what 
the secular therefore means. A discursive method allows for clear and precise understanding, not of a definite identity of the spaces themselves, but of the relationships between the formations of a "religious space" and a "secular space," without having to devise a scheme to explain the uniformity of religious practice universally. At any rate, such essentializing language eventually contradicts itself. While discursive methodologies avoid this contradictory pitfall by avoiding essentialized categories, this does not mean that they necessarily fall into the trap of reducing all phenomena as "religious," or that all meaning is radically subjective, or that analysts are left without the analytic tools necessary for comparative practices, as Riesebrodt argues. In fact, Riesebrodt's methodology is no less a victim of the contradictory process behind the essentializing and mutually exclusive language he uses. This chapter will elaborate on the contradictions present in his methodology by drawing on the internal incoherence of two of the more foundational aspects of his theory, which has implications for the importance of the study of religion. These two aspects are interrelated and form the basis, not only of his theory, but of the very process that this thesis argues against when attempting to compare religions and religious phenomena. The first foundational aspect of Riesebrodt's methodology which will be critiqued is his understanding that religions are dependent on "superhuman" powers. The second foundational aspect leading to inconsistency is his interpretation that religions are dependent on a centralized institution which regulates, mediates, and rationalizes the discursive relationship between the "superhuman" powers and their religious believers. The final section of this chapter will follow Jacques Derrida's work in "Faith and Knowledge: The Sources of Religion at the Limits of Reason Alone" to criticize and unearth the problems with Riesebrodt's 
typology and how such a typology masks the negotiative process and genealogical relationship between religious and secular spaces within Western secular societies. The reason for emphasizing the discursive nature of institutions is, again, that public spaces are defined by them. The public school is one such institution understood as a cornerstone of the public, secular square (despite education historically being associated with religious institutions), and is thus a wonderful example for discussion. Not only that, the public school's place within the secular square makes it instrumental in the formation of the categories under scrutiny and complicit in allowing simplistic definitions of religious and secular to run free. It is my opinion that currently, the public school does not adequately equip its students with the sufficient level of education for them to intelligently negotiate the formation of spaces, and that some of the blame lies in relying on simplistic definitions of what is "religious" and "secular".

\section{THE RELIGIOUS AND SECULAR IN RIESEBRODT'S METHOD}

Martin Riesebrodt in The Promise of Salvation has posited a theory of religion as a response to what he perceives as the paltry state of present research on religion: "it was chiefly the unsatisfactory state of research on religion that led me to propose a theory of religion. ${ }^{39} \mathrm{He}$ has a particular dislike for discourse theory and deconstructionism, which this thesis uses as its method. Riesebrodt states

I oppose my theory of religion to deconstructionism, which...hinders serious research... Such a position cannot be maintained in the long run, for in deconstructing a given concept one has to make use of other

\footnotetext{
${ }^{39}$ Ibid, pg. xi
} 
concepts...This obviously holds for all concepts that might be substituted for the concept of religion. ${ }^{40}$

Riesebrodt sees the overemphasis on language and linguistics in postmodern analysis as the principle weakness in their methodology, which to him is to focus on an elitist practice. "They tend to focus on the discourses of political and intellectual elites, while ignoring the deviating practices of large population groups." ${ }^{41}$ However, to ignore the linguistic justifications and rationales for behavior is to background an important aspect for understanding their genealogical history, current justification, and future trajectory. The full significance of denying or ignoring the linguistic justifications for behavior will be explored in the next chapter with respect to religious justifications for violence. For now, the issue with Riesebrodt's typology and his disregard for taking into account the linguistic justifications for religious and secular identity is that it does not allow for the study of new and emergent traditions, such as Deep Ecology or the “cafeteria spirituality" phenomenon, which do not rely on a central institution to define their identity; thus, his theory backgrounds their participation and effect on both the religious and secular landscapes.

Riesebrodt's theory centers on the interaction between religious institutions and the "superhuman" powers, which direct the practices of the religious masses through religious institutions. ${ }^{42}$ These two conditions are what enable Riesebrodt to make the

\footnotetext{
${ }^{40}$ Ibid, pg. 6

${ }^{41}$ Ibid, pg. 11

${ }^{42}$ This is how Riesebrodt defines what he means by "superhuman" powers. "Establishing contact can mean...interaction through symbolic actions such as prayers, chants, gestures, formulas, sacrifices, vows, or divination. Second, establishing contact in the sense of manipulation my take place, for example...performing 'magical' acts. Establishing contact can also mean temporary...fusion with superhuman powers...Finally... activating super-human potential that slumbers within a person...All such
} 
following claim from his definition of religion: "The definition also avoids the absurd, overly broad understandings of religion according to which soccer games, shopping at a supermarket, or barbecues are religious phenomena.. ${ }^{, 43}$ The ultimate purpose of a definition of religion for Riesebrodt, as well as what governs his arbitration between "religious" and "secular" statements, is a desire for the construction of an analytical concept to differentiate "religious" behavior from "non-religious" behavior. "General concepts are indispensible for any cognitive ordering of the world... We need a conceptual framework that allows us to make comparisons and thus to precisely describe and qualify similarities and differences." ${ }^{44}$ However, such rigid categorization inevitably renders the various practices, justifications, and formations of "institutionalized" religions incoherent when faithfully applied universally. One such practice which could easily be misconstrued when viewed from the perspective of a Western observer is the Chinese practice of ancestor "worship." Unless elaborated by the practitioner's own understanding of the practice, this practice becomes difficult to pigeonhole precisely as a religious practice, and thus as a religious space, according to Riesebrodt's method. While these practices are and have been regulated by Confucian, Daoist, and Chinese Buddhist institutions, China's communist government has also appropriated the practice and promotes the custom despite its self-understanding as a secular and irreligious state. So who is the legitimate institutional authority to deem the practice of ancestor "worship" as "religious" or "secular?" Moreover, the silencing of the interdependent relationship

\footnotetext{
practices, which aim at establishing contact with superhuman powers, I call interventionist practices." Riesebrodt, p. 75

${ }^{43}$ Riesebrodt, pg. 16

${ }^{44}$ Ibid, pg. 16
} 
between the two spaces backgrounds how the constitutive elements of each space may fall between either of the two categories depending upon the environment. What this means is, if the Chinese secular government silences the religious genealogy behind the practice, to one merely observing it, the practice would appear as a secular ritual. A discursive approach would take the phenomenon and demonstrate how it has been understood differently in different contexts, without the necessity of having to make a judgment one way or the other. Foucault illustrates the process behind what he terms "systems of formations," which is relevant to the formation of concepts such as the secular and religious. "What are described as 'systems of formations' do not constitute the terminal stage of discourse, if by that one means the texts (or words) as they appear, with their vocabulary, syntax, logical structure, or rhetorical organization. Analysis remains anterior to this manifest level, which is that of the completed construction...in short, it leaves the final placing of the text in dotted outline." ${ }^{, 45}$ An important implication that discursive approaches bring to light is that, whatever conclusion is drawn, whatever object is described, and what task is assigned, it must always be drawn and set in a context first. Nothing is simply empirical. Before going further into a critique of Riesebrodt's rigid methodology, it is important to understand and respond to his underlying objection to discourse theory. He writes,

If one accepts the premises of discourse theory, then all concepts are gradually dissolved into ultimately incomparable particularisms. In my view, we cannot adequately describe the uniqueness of social phenomena without general concepts and comparisons. Moreover, in contrast to this historically relativist view, it turns out that types of discourse are quite similar over and beyond periods and cultures. ${ }^{46}$

\footnotetext{
${ }^{45}$ Foucault 1976, pg. 75

${ }^{46}$ Ibid, pg. 11 - 12
} 
With respect to methodological issues, Riesebrodt's principal objection to discursive approaches is that they leave the analyst without conceptual tools, since there is no outside "check-list" to facilitate the analysis. However, his objection is ungrounded, discourse theory does not consider the "ultimate" precariously contingent dimensions of an object incomparable since they are in constant flux; on the contrary, it is the very fact that these dimensions are in flux, that they dismember themselves and rearrange themselves, leaving traces of themselves in this migratory activity, which enables us to compare and analyze phenomena. When these dimensions and particularities are in constant flux they do so according to discursive rules being regulated and authorized by various agents and impersonal processes embedded within the epistemic framework they operate. However, different epistemic frameworks exist across time and space, leading to different formulations of different objects, which may or may not resemble their functioning and understanding in other frameworks. Foucault emphasizes the spontaneity in the formation of discursive practices,

Thus it is not a change of content (refutation of old errors, recovery of old truths), nor is it a change of theoretical form (renewal of paradigm, modification of systematic ensembles). It is a question of what governs statements, and the way in which they govern each other so as to constitute a set of propositions which are scientifically acceptable, and hence capable of being verified or falsified by scientific procedures. ${ }^{47}$

Talal Asad takes this challenge from Foucault and applies these parameters to the study of religion, concluding not that one cannot study "religion" as Riesebrodt understands, but that one must always temporalize and historicize the particular tradition one is studying:

\footnotetext{
${ }^{47}$ Foucault 2010, pg. 54
} 
From this it does not follow that the meanings of religious practices and utterances are to be sought in social phenomena, but only that their possibility and their authoritative status are to be explained as products of historically distinctive disciplines and forces. The anthropological student of particular religions should therefore begin from this point, in a sense unpacking the comprehensive concept which he or she translates as 'religion' into heterogeneous elements according to its historical character. $^{48}$

Since the public school system has been invested as an authority on the epistemological construction of these categories and governs the authoritative statements in its production of knowledge, as are embodied by its students, it plays a role in how these concepts are formulated both imaginatively and phenomenologically. I am not trying to stay that religions and religious people do not have a voice in what religion means, or that the public school is the only secular author of its understanding of religion, but that the public school is invested with properly inscribing into the students what the world is and how to engage it, which has ramifications on the construction of religious/secular spaces, and how we engage in other formulations of such spaces. The point is that the public school holds a special position, since everyone is mandated by the government to an education, both to the perception and expectation of the quality of knowledge produced and the entailment to constantly reassess its epistemological reproduction. Also, whenever misrepresentations of other religious traditions occur within the dominant society, whether through problematic definitions constructed "to simplify their lives," or for political motivations to demonize the other, the public school should be charged with the obligation to deconstruct such misrepresentations by providing students with a sufficient level of religious literacy to do so. Relying on

\footnotetext{
${ }^{48}$ Asad 1993, pg. 54
} 
people's "common sense" to approaching the concept of what a religion is and what the secular is, is not an adequate or viable approach to such influential and important spaces.

Riesebrodt's emphasis on the institutional character for defining religion directly feeds into the second bone he has to pick with postmodern theoreticians concerning their uneasiness with establishing such rigidly defined categories. He focuses his second objection on Talal Asad's claim that there is no universal definition for the term religion. The following passage is drawn directly from Asad's own work and unabashedly articulates the sentiment Riesebrodt finds so troubling.

What we call religious power was differently distributed and had a different thrust...Nevertheless, what the anthropologist is confronted with, as a consequence, is not merely a collection of elements and processes that we happen to call 'religion.' For the entire phenomenon is to be seen in large measure in the context of Christian attempts to achieve a coherence in doctrines and practices, rules and regulations, even if that was a state never fully attained. My argument is that there cannot be a universal definition of religion, not only because its constituent elements and relationships are historically specific, but because that definition is itself the historical product of discursive processes. $^{49}$

In Riesebrodt's view this argument is illogical, there has to be some essence that is being discussed in order to make sense of the world. He writes,

Asad's claim that there could be no universal concept of religion is neither sufficiently grounded nor logically valid...even if one adheres to the view that religion has a different structure, function, and meaning in different social formations, this view requires a concept of religion on which such a claim can be grounded. ${ }^{50}$

However it would be wise to consult Foucault and his wariness towards claiming such extemporal positivities. Such descriptions remove the environmental context from

\footnotetext{
${ }^{49}$ Asad 1993, pg. 29

${ }^{50}$ Riesebrodt, pg. 11
} 
which concepts are generated. To stubbornly insist on external positivities which ultimately backfires when the object referred to or the person embodying the knowledge migrates to a different environment, and misrepresents the new localized context of whatever is conceptualized. This does not bode well for Riesebrodt's insistence on a universal essence to any concept precisely because he is pretending to give the conditions for the emergence of religion regardless of the environmental conditions that affect such an emergence.

Descriptions that are directed not toward knowledge as an instance of formation but to the objects, forms of enunciation, concepts, and finally, to the opinions which they give rise; descriptions that will, nevertheless, only remain legitimate on the condition that they do not pretend to discover the conditions of something as a scientific discourse. ${ }^{51}$

The troublesome issue with science and scientific discourse is the broad assumption in our modern society to take its conclusions uncritically as an extemporal, ahistorical "Truth" or as something essential, similar to what Riesebrodt is attempting to construct by defining the term "religion." Part of the problem is that one can never prove the underlying foundations of a system of thought from within the system. Thus, positing a foundation ignores the very context out of which the system develops and in which it functions. The backgrounding of the context from which systems of forms objects, even through the scientific method, leads to problematic ideological assumptions. Foucault illustrates this problem elsewhere when such pretensions are left uncriticized, "One of the great problems that arose was that of the political status of science and the ideological functions it could serve. ${ }^{, 52}$ It is this precise sentiment that encumbers Asad from making

\footnotetext{
${ }^{51}$ Foucault 2003, pg. 419

${ }^{52}$ Ibid, pg. 300
} 
a claim to a universal definition for religion, undermining the rationale for Riesebrodt's

whole project.

Yet the insistence that religion has an autonomous essence - not to be confused with the essence of science, or of politics, or of common senseinvites us to define religion (like any essence) as a transhistorical and transcultural phenomenon. It may be a happy accident that this effort of defining religion converges with the liberal demand in our time that it be kept quite separate from politics, law, and science-spaces in which varieties of power and reason articulate our distinctly modern life. This definition is at once part of a strategy (for secular liberals) of the confinement, and (for liberal Christians) of the defense of religion. ${ }^{53}$

Then for Riesebrodt to make a valid claim for a universalized concept of the term "religion" to be applied within the framework of social scientific comparative analysis, the concept would principally need a method that arrives at a definition which is historically specific yet fluid enough that it does not betray any ulterior motive, privilege, or prejudice to any particular cultural construction as the universal conditions for defining "religion;" nor can the definition be so constrained as to choke any emergent religious movement from the conceptualization of the term. Also for Riesebrodt, the crux of a religion should be self-sufficient, i.e. a religion should not have to depend upon another religion to define itself institutionally outside of the preliminary historical development of the religion. To be fair, this does not mean for Riesebrodt that there is no room for syncretism or that every religion develops each of its dimensions sui generis, but that, for example, Buddhism is clearly institutionally demarcated and independent from the institutions of Hinduism, Confucianism, Islam, Daoism, Christianity, etc. He believes he achieves this aim by following Max Weber's ideal types,

\footnotetext{
${ }^{53}$ Asad 1993, pg. 28
} 
The continuing relevance of Max Weber's sociology consists not least in the fact that he was fully aware of this problem...His elaboration of types constantly distinguishes between general types of action and culturally specific forms. Furthermore, Weber's ideal types are deliberately constructed to serve not as classification schemes but as instruments for the precise description of historically specific formations. $^{54}$

For Riesebrodt, establishing contact with "superhuman" powers is not enough to term this discursive relationship "religion." Individual religious practice and religious behavior does not alone constitute a religion for Riesebrodt. "Regulations regarding behavior are, however, valid as religious practices only when they occur in accord with the will, the principles, or the sanctions of superhuman powers." ${ }^{, 55}$ Riesebrodt qualifies "religious" actions and practices from "religion" proper with religion being "the complex of religious practice." ${ }^{, 56}$ Riesebrodt articulates the difference by suggesting that

Someone who practices Zen meditation on Mondays, turns tables on Tuesdays, lays out Tarot cars on Thursdays, and goes to Mass on Sundays is performing religious acts, but the systematic connection among them is lacking. If this connection is produced only subjectively, then these practices lack the social character of a religion. ${ }^{57}$

Each example of a practice presented by Riesebrodt in the previous quote--Zen meditation, turning tables, Tarot cards, and Mass--has some connection to a religion and religious practices. What upsets Riesebrodt is that someone would observe such a practice and dub it a religion. He has described this process as what some have termed as the modern phenomenon of "cafeteria spirituality." If Riesebrodt is not concerned with an articulate and theologically pure system of practice, and understands practice itself as

\footnotetext{
${ }^{54}$ Riesebrodt, pg. 18 - 19

${ }^{55}$ Ibid, pg. 76

${ }^{56} \mathrm{Ibid}$

${ }^{57}$ Ibid
} 
the crux of religion, with that practice regulated and confirmed by a group of people according to the "will, principles, and sanctions of superhuman powers," then how does the example of the "cafeteria spirituality" of the religious person mentioned above not equal a practice of religion? And this is relevant for the scientific studies of religion because, as Riesebrodt grudgingly notes, such forms of "religious practice" are increasing in numbers of practitioners,

Even if there is an unmistakable trend toward religious voluntarism and subjectivism, especially among younger members of the middle class in Western countries... 'Spirituality' may prove in the long run to be transitional phenomena. We certainly cannot exclude the possibility that future generations will turn to more stable religious institutions. ${ }^{58}$

While he does have a point about the future of established religious traditions, how is his hostility towards the current "loose" religious practices of the West justified or any different from a Theravadin lay person going to a Brahman priest for help with something, or a Japanese Shinto priest going to a Zen retreat for a few weeks or months to escape from the city? Riesebrodt himself has to admit to the lax institutional parameters of the East:

An important difference between the Abrahamic religions and East Asian religions lies in the formers' claim to exclusivity. Whereas Judaism, Christianity, and Islam expect their adherents to respect the boundaries between the traditions, East Asian religions, with the exception of Nichiren Buddhism, make no such claim. No Japanese is forced to choose between Shinto and Buddhism; no Chinese must choose between Daoist, Buddhist, or 'popular religious' practices. On the contrary: for the most part, even Chinese Japanese rulers cultivated a variety of religious traditions at their courts, and sometimes practices these various forms privately. ${ }^{59}$

\footnotetext{
${ }^{58}$ Ibid, pg. 179 - 180

${ }^{59}$ Ibid, pg. 97 - 98
} 
Riesebrodt has no answer for the question, from an institutionally differentiated point of view, how are the general religious practices of the East any different from the situation with the phenomenon of "cafeteria spirituality" in modern Western countries, the practitioners of which also have an array of religious practices from differing institutions from which to choose? Since there are such heavy and exclusive conditions within Riesebrodt's typology, ultimately his theory should be considered untenable: from within his own criteria for what constitutes a good theory. Moreover, when applied universally, this typology misrepresents, not only religious others in different cultural contexts, but also the differing and changing religious practices and climate of our own society by misrepresenting and excluding citizens within secular societies who are outside of such rigid categorization, such as Deep Ecologists. In this way, discursive approaches provide a better methodology for the study of religion than this typological method which confuses the functioning of religion in different societies and does not allow the religious practitioner's themselves to articulate their own understanding of their religion, however nonsensical or annoying this maybe to Riesebrodt. The most serious issue however is that Riesebrodt's typology does not give the requisite space for new religious traditions to emerge, since by definition they would fall outside of Riesebrodt's typology because their institutions are not yet developed. Also, by using discursive methods, different trends within religions can be highlighted to show commonalities and differences without turning every phenomenon into a religion.

Discursive methodologies, by emphasizing the locality, temporality, and trajectory of the constituent parts of a concept or phenomenon, unearth the fact that these dimensions and particularities are in constant flux and are able to come together and 
break away. The teaching about religions enhances education by providing not only a critical lens to critique with, but also a whole archive for students to intellectually mine. Also, when these particularities and dimensions come together and break away, it happens for a reason and according to discursive rules, which are negotiating the outline of these concepts and spaces between the differing and complex actors within the environment. Foucault emphasizes the spontaneity embedded in such formations of discursive practices,

Thus it is not a change of content (refutation of old errors, recovery of old truths), nor is it a change of theoretical form (renewal of paradigm, modification of systematic ensembles). It is a question of what governs statements, and the way in which they govern each other so as to constitute a set of propositions which are scientifically acceptable, and hence capable of being verified or falsified by scientific procedures. ${ }^{60}$

Talal Asad takes this concept from Foucault and applies it to the study of religion, concluding not that one cannot study "religion" as Riesebrodt's theory understands, but that one must always temporalize and historicize the particular tradition one is studying:

From this it does not follow that the meanings of religious practices and utterances are to be sought in social phenomena, but only that their possibility and their authoritative status are to be explained as products of historically distinctive disciplines and forces. The anthropological student of particular religions should therefore begin from this point, in a sense unpacking the comprehensive concept which he or she translates as 'religion' into heterogeneous elements according to its historical character. ${ }^{61}$

\footnotetext{
${ }^{60}$ Foucault 2010, pg. 54

${ }^{61}$ Asad 1993, pg. 54
} 


\section{RELIGIOUS AND SECULAR FROM A DISCURSIVE PERSPECTIVE}

As was explored in the previous section of the chapter, Riesebrodt, by centralizing his theory of religion as belief in "superhuman powers" to overcome the difficulties of life, is creating what Kant termed as "the religion of cult alone." As Jacques Derrida argues and I agree that, "the religion of the cult alone seeks 'favours of God,' but at bottom, and in essence, it does not act, teaching only prayer and desire. Man is not obliged to be better." 62 This is not to say that according to Riesebrodt religions do not act in society, but that religious people only act religiously when they act in concert with their religious institutions, either as the practice of religion, or as religiously sanctioned critique of secular society, such as religious cultures of violence. People would also act religiously in this framework when their actions are directed towards their own religious institutions for religious reasons. The point that I am attempting to make is that Riesebrodt's understanding of religion falls into this category, and this is problematic for the study of religion because, as we have seen, not all religious activity acts in line or is directed against an institution.

Interestingly, the "religion of cult alone" is completely different from the other form of religion that Kant described, "moral religion" or "reflecting faith." Derrida also comments on this religious type in the following passage, which is irrespective to any "superhuman" power and not dependent on any religious institution. His commentary on "moral religion" is insightful in illustrating Riesebrodt's uneasiness with fitting religions of this type within his framework: "Moral religion, by contrast, is interested in the good conduct of life; it enjoins him to action, it subordinates knowledge to it and dissociates it

\footnotetext{
${ }^{62}$ Derrida 1996, pg. 10
} 
from itself, prescribing that man become better by acting to this end. ${ }^{, 63}$ In other words, Derrida's take on Kant's category of "moral religion" is a religion which derives authority not on "superhuman" powers per se, but on the very human ability to observe the phenomenal world and empirically draw conclusions from it. Not only do "moral religions" proclaim these empirically based conclusions as "true" and "objective," they also authorize a certain ethic based on the conclusions drawn from this rational process and have it defined as "the good." If that was not enough, this "good" is presented as somehow unaffected by this very process, conducted every step of the way by finite people. Finally, "moral religions" universally subscribe everyone to its precepts at a theoretical level, because they understand everyone to have access to "the good" through their rational faculties, each on his or her own, regardless of the cultural and environmental context.

Derrida's commentary on Kant's "moral religion" is insightful in problematizing Riesebrodt's conceptualization of religion because the typical idea behind Western approaches to science would easily fall into such a category. The scientific method is used to alleviate problems by drawing empirical conclusions from researching the surrounding environment and providing some knowledge that is to be used in relationship to that environment in solving the research problem. Riesebrodt stated that the usefulness of his concept is that it clearly allows the researcher to demarcate between religion and non-religion, namely secular institutional spaces, which are not devoted to developing "superhuman" powers but devoted to maintaining a social order determined by human capabilities. "By the concept of secularization, therefore, I refer solely to the process of

\footnotetext{
${ }^{63}$ Ibid, pg. 10
} 
institutional differentiation through which secular spaces -that is, social spheres free of religious premises and norms-emerge." ${ }^{, 64}$ Here we are in a difficult position. If we were to take Derrida's working of Kant's theory and apply it to Riesebrodt's typology, it problematizes not only Western science, but all Western "secular" institutions, such as the public school. To maintain the distinctions of "religious" space and "secular" space, discourse is inherent for the recognition of another space, an undetermined or blurred space, to enable a process of differentiation between the first two. Riesebrodt, by placing a solid wall between religion and the secular, has closed off the discourse, necessarily blurry and complex, which would differentiate between the two. In effect, Riesebrodt's presentation of the secular appears no different from Kant's "moral religion," undermining the usefulness of his method. Conversely, Derrida explains why he begins his discussion on religion with Kant's "moral religion," which he also refers to as "reflecting faith," and its dependency on "dogmatic faith" and its parallel in "religion of the cult alone," to maintain its uniqueness.

Because it does not depend essentially upon any historical revelation and thus agrees with the rationality of purely practical reason, reflecting faith favours good will beyond all knowledge. It is thus opposed to 'dogmatic faith'. If it breaks with this 'dogmatic faith', it is in so far as the latter claims to know and thereby ignores the difference between faith and knowledge. Now the principle of such an opposition - and this is why I emphasize it - could not be simply definitional, taxonomic or theoretical; it serves not simply to classify heterogeneous religions under the same name; it could also define, even for us today, a place of conflict, if not of war, in the Kantian sense. Even today, albeit provisionally, it could help us structure a problematic. ${ }^{65}$

The insight provided by Derrida's analysis is that "moral religions," by assuming that they are always acting for the good of humanity become no less dogmatic in its

\footnotetext{
${ }^{64}$ Riesebrodt, pg. 175

${ }^{65}$ Derrida 1996, pg. 10
} 
methods, and no less ideological in justifying its ends, than a "religion of the cult alone." When both are present in a society, to alleviate the tension generated by the antagonism between the two to define the good, society necessitates a viable discourse to enable a differentiation between the spaces of the two poles. The implication of this to my thesis is, even when these characteristics are represented in a given space and termed "religion" and "secular" rather than "religion of the cult alone" or "moral religion," if one side completely closes itself off from the other, the distinction between the two becomes blurred. Hence one of the reasons why it is so important to have a religiously literate citizenry is for the citizens of such a society to thoughtfully and carefully negotiate between such boundaries.

When the state of the relationship deteriorates to such a degree that the distinctions are not only blurred, but discourse has been silenced, the climate becomes one of war, or at least the environment ripens for violence outside the purview of authorized institutions. This occurs because the differences within the society are backgrounded to promote the interests of those who are silencing the deviant voices; these deviants are then redefined and reincorporated into the social body but misrepresented. So, if religions are solely understood as being concerned with otherworldly affairs, as "religions of the cult alone," then any movement by a religious institution to act in the world would need to comply with the arbitrary conditions of "secular reason" to be taken seriously. Consider, for instance, the Danish cartoon contained a depiction of the prophet Muhammed as a suicide bomber. There is no "secular" reason to not depict the prophet Muhammed, only a devotional reason. However, when the Danish government protects the newspaper's rights to free speech 
over Muslims who were offended by the representation, on account of the irrationality of their request as per the secular viewpoint, they are being no less ideological because the conception of free speech as the freedom to say absolutely whatever one wants is no less a myth. Moreover, there is a direct genealogical relationship between the Western construction of universal human rights and Protestant Christian theology that is present in their justifications. And Muslims pick up on this all over the world and respond by saying that Western secular societies have no deference towards other religions; particularly violent or disenfranchised Muslims may respond with violence to this perceived humiliation. Of course this movement to violence backgrounds voices within Islamic communities themselves against responding with violence. Derrida illustrates how Islamic terrorists silence moderate Muslims when performing acts of violence by speaking in its name and the epistemological quandary that ensues, "Islam is not Islamism and we should never forget it, but the latter operates in the name of the former, and thus emerges the grave question of the name. ${ }^{, 66}$ As Islamic terrorism speaks for Islam as a whole, so does the "modern project" speak for the West, and the world really, universally. The fact that our secular society is grounded in particular religious assumptions generates the conditions for people in the West to have to make a choice, or to use Derrida's terminology, a response, to accept the particular Protestant Christian assumptions of the "modern project" or to criticize them, but there is no escape from addressing them. "They would then constitute a response to everything that our idea of democracy, for example, with all its associated juridical, ethical and political concepts, including those of the sovereign state, of the citizen-subject, of public and private space

\footnotetext{
${ }^{66}$ Ibid, pg. 6
} 
etc., still entails that is religious, inherited in truth from a determinate religious stratum. ${ }^{, 67}$ To say that one is not able to escape from making a response is not to say that one is not free, but the response itself is an aspect of the shared environment.

There we might have, perhaps, a pre-definition: whatever little may be know of religion in the singular, we do know that it is always a response and a responsibility prescribed, not chosen freely in an act of pure and abstractly autonomous will. There is no doubt that it implies freedom, will and responsibility, but... will and freedom without autonomy. ${ }^{68}$

Derrida sees religion as the response to one's situation, "Religion, in the singular? Response: 'Religion is the response.' Is it not there, perhaps, that we must seek the beginning of a response. ${ }^{.69}$ This initial approach to the concept of religion is highly controversial. First, as Derrida notes, it bears the question, to whom or what is one responding? And second, there is a problem with attempting to seek an origin to the question, or in other words, solving the first problem engenders another problem. Foucault warns us of searching for origins.

Why does Nietzsche challenge the pursuit of the origin...First, because it is an attempt to capture an exact essence of things, their purest possibilities, and their carefully protected identities; because this search assumes the existence of immobile forms that precede the external world of accident and succession. ${ }^{70}$

The problem in following Derrida's approach is that one might end up back to Riesebrodt's position of religion as belief in "superhuman" powers. However, this is only because of the pervasive assumptions attached to religion as a concept already. So let us entertain this approach by Derrida in investigating his string of thought while

\footnotetext{
${ }^{67}$ Ibid, pg. 26

${ }^{68}$ Ibid, pg. 34

${ }^{69} \mathrm{Ibid}$, pg. 26

${ }^{70}$ Foucault 2010, pg. 78
} 
noting that Derrida does situate himself temporally and historically when speaking about the topic.

We represent and speak four different languages, but our common 'culture,' let's be frank is more manifestly Christian, barely even Judaeo-Christian. No Muslim is among us, alas...No representative of other cults either. Not a single woman! We ought to take this into account: speaking on behalf of these mute witnesses without speaking for them, in place of them, and drawing from this all sorts of consequences. ${ }^{71}$

When Derrida frames the question of what is religion around religion as a response, the "whom" or "what" to which one is responding is always an other, some exteriority which initiates a call and assumes an ability to respond by the called. The necessity of some exteriority is why "moral" religions have to objectify their conclusions and dissociate these objectifications from themselves. "No response, indeed, without a principle of responsibility: one must respond to the other, before the other and to one's self. And no responsibility without a given word, a sworn pledge, without a pledge, without an oath, without some sacrament or ius iurandum." "72 The previous quote's emphasis on the call and response nature of religion is an obvious reference to the response by Abraham to God's call, and it is problematic when carrying this understanding of religion over to other religions. This should not concern us however problematic it may appear at the moment because what is being investigated is the relationship between religion as it is understood within Western society and the space that is created in its "absence." So, on the one hand, if God is immediately posited as the other who is waiting for a response, as one would tend to do within a typical Western context, then one has created a mechanical type of God. Derrida comments,

\footnotetext{
${ }^{71}$ Derrida 1996, pg. 5

${ }^{72}$ Ibid, pg. 26
} 
Presupposed at the origin of all address, coming from the other to whom it is also addressed, the wager of a sworn promise, taking immediately God as its witness, cannot not but have already, if one can put it this way, engendered God quasi-mechanically. A priori ineluctable, a descent of God ex machine would stage a transcendental addressing machine. One would thus have begun by posing, retrospectively, the absolute right of anteriority, the absolute 'birthright' of a One who is not born. $^{73}$

Also, if one immediately places God as the one questioning, then it completely kills the need for a separate space between the person witnessing to God and God Itself. "But with God, a God that is present, the existence of a third that is absolute, all attestation becomes superfluous, insignificant or secondary."74 Derrida picks up on the idea of testimony and its presence in our society. It is well known that in the past, court rooms would ask witnesses to swear on the Bible and to God that they promised to tell the truth, the whole truth, and nothing but the truth. This practice continues to this day, but in a "secularized" format. "For in taking God as witness, even when he is not named in the most 'secular' pledge of commitment, the oath cannot not produce, invoke or convoke him as already there, and therefore as unengendered and unengenderable, prior to being itself: unproducible. And absent in place."75 On the other hand, even if God is not invoked or respected, as in Western "secular" spaces, there is a sense of emptiness on that side which rushes to fill that void. The "death" of God within modern society has created an anxiety with relation to that void. "Everything begins with the presence of that absence. The 'deaths of God', before Christianity, in it and beyond it, are only figures and episode. The unengendered thus re-engendered is the empty place. Without

\footnotetext{
${ }^{73}$ Ibid, pg. 27

${ }^{74} \mathrm{Ibid}$

${ }^{75} \mathrm{Ibid}$
} 
God no absolute witness. No absolute witness to be taken as witness in testifying." ${ }^{, 76}$ In such a situation then, to relieve the tension and anxiety caused by the removal of God from what is being attested to, human reason then fills the role of God to judge and rectify human behavior. Within the Western Christian heritage, the removal of God as the locus of truth has been coupled with a virulent and angry rejection of the concept, hence never really absent in its totality.

In the irrepressible invoking of a witness, God would remain then one name of the witness, he would be called as witness, thus named, even if sometimes the named of this name remains unpronounceable, indeterminable, in short: unnameable in his very name; and even if he ought to remain absent, non-existent, and above all...unproducible. God: the witness as 'nameable-unnameable', present-absent witness of every oath or of every possible pledge. ${ }^{77}$

God remains as a ghost so to speak. This brings the paradox in Western society, even if one wants to do away with "religion" as belief in "superhuman" powers, one in the West cannot completely rid oneself of God's presence because of the ubiquitous legacy of Christianity within our society and the superabundance of conclusions drawn from that legacy which linger in so called "secular" spaces. Even if one where to let go of the concept of "God," people just replace God with themselves as the final arbiter of their decisions, but not in a totally liberated sense. Richard Fenn holds the view of secularization being critiqued and describes the secularization process as:

The same drive toward freeing the individual from background institutions has produced an egalitarian impulse that levels a number of moral and aesthetic distinctions that used to accompany social class...Individuals now must stand on their own ground...True secularity also accepts a psychological divorce, as it were, between the individual and larger society. The terms of the divorce stipulate that the

\footnotetext{
${ }^{76} \mathrm{Ibid}$

${ }^{77}$ Ibid
} 
individual will not be able to take narcissistic satisfaction from collective illusions about the importance of the larger society; one implication of this settlement is that the larger society will have more difficulty in placing sacrificial demands on the individual... Secularization takes the mystery out of time. ${ }^{78}$

However, the removal of the "mystery of time," i.e. religion, does not rid one of choosing one from the other. What Fenn does not realize is, despite the removal of religious institutions from secular spaces, there is still a constant choice being made between the two. If society continues with the terms of divorce, the "removal" of the "narcissistic" influence of religion, as Fenn glorifies in his view of secularization, violence erupts from the other. Moreover, secular institutions are no less mysterious in their relations to time when they implement terminology such as "modernity," "invisible hand," and "development" to bind the larger society together and explain its functioning. This is why Derrida continues to mention responsibility and how everyone is implicated in negotiating the terms between secular and religious.

As for the response, it is either or. Either it addresses the absolute other as such, with an address that is understood, heard, respected faithfully and responsibly; or it retorts, retaliates, compensates and indemnifies itself in the war of resentment and of reactivity. One of the two responses ought always to be able to contaminate the other. ${ }^{79}$

What Derrida is saying in the previous passage is that both spaces are tied together, even if it is to define themselves against each other. Moreover, those testifying should recognize this symbiotic relationship and the possibility of redefinition. The implication of realizing the probability of having to redefine oneself in light of another set of circumstances is brought forth in the next passage by Derrida, who implicates the conclusions drawn from the Enlightenment period.

\footnotetext{
${ }^{78}$ Fenn, pg. 12 - 13

${ }^{79}$ Derrida 1996, pg. $28-29$
} 
Light (phos), wherever this arche commands or begins discourse and takes the initiative in general... as much in the discourse of philosophy as in the discourses of a revelation or of a revealability, of a possibility more originary than manifestation. More originary, which is to say, closer to the source, to the sole and same source. Everywhere light dictates that which even yesterday was naively construed to be pure of all religion or even opposed to it and whose future must today be rethought (Auflarung, Lumieres, Enlightenment, Illuminismo). ${ }^{80}$

The real crux of the problem is that one is not certain which of the two responses is "correct:" "It will never be proven whether it is the one or the other, never in an act of determining, theoretical or cognitive judgement. This might be the place and the responsibility of what is called belief, trustworthiness or fidelity, the fiduciary, 'trust' in general, the tribunal of faith. ${ }^{, 81}$ But how to have the adherents of either ideology recognize the underlying faith behind their epistemic frameworks, and the mutual dependency of either category to the other.

The importance of Derrida's insight is that it brings to light the underlying religious processes behind otherwise seemingly benign words in our secular vocabulary, and it enlightens us to the very Christian undertones prevailing in our "secular" society, which are spread globally through globalization, or the "modern project" as referenced above. Derrida uses his own term for the globalization process, globalatinization, which has the same understanding as the "modern project": "We shall return to this laterglobalatinization (this strange alliance of Christianity, as the experience of the death of God, and tele-technoscientific capitalism) is at the same time hegemonic and finite, ultrapowerful and in the process of exhausting itself." 82 Moreover, the problem with the

\footnotetext{
${ }^{80}$ Ibid, pg. 6

${ }^{81}$ Ibid, pg. 29

${ }^{82}$ Ibid, pg. 13
} 
backgrounded Christian doctrines which are embedded in the form of capitalism eschewed from this particular matrix, is not only that they are backgrounded and uncriticized, but they make a universal claim, but a claim that on account of its cultural and environmental grounding, can never fully realize its ambition. The universalizing ambition is exacerbated when there are attempts, such as Riesebrodt's theory, to dissociate from religion all of its constituent dimensions to retain a core that is somehow free from politics, and vice versa.

One would have to dissociate the essential traits of the religious as such from those that establish, for example, the concepts of ethics, of the juridical, of the political or of the economic. And yet, nothing is more problematic than such a dissociation. The fundamental concepts that often permit us to isolate or to pretend to isolate the political restricting ourselves to this particular circumscription - remain religious. ${ }^{83}$

The method by which American "secular" society retains its religious character is through the uncritical absorption of its religious descent. In other words, as the previous paragraph mentioned, even with the rejection of the concept of God, the function of the concept still leaves an anxiety with respect to the void created by God's "death" to the justification of the other dimensions of our secular society, which is filled with a robust humanism. The problem is that any position is ultimately taken up by faith rather than reason or knowledge, regardless if the one who is an atheist realizes it or not. Derrida comments on the pervasiveness of religion throughout our culture by focusing on language and on how language changes over time to mask the etymology of our vocabulary so much so that it obscures us from the liquidity of these concepts, creating problems when applied to others.

\footnotetext{
${ }^{83}$ Ibid, pg. 25
} 
From here on, the word 'religion' is calmly (and violently) applied to things which have always been and remain foreign to what this word names and arrests in its history. The same remark could apply to many other words, for the entire 'religious vocabulary' beginning with 'cult', 'faith', 'belief', 'sacred', 'holy', 'saved', 'unscathed'...Globalatinization (essentially Christian, to be sure), this word names a unique event to which a meta-language seems incapable of acceding although such a language remains, all the same, of the greatest necessity here... What is involved here is a Latinization...rather than globality. ${ }^{84}$

The anxiety caused by a lack of faith spurs a temptation to knowledge and to make claims to knowledge. It is the anxiety to know that spurs simplistic attempts at defining religious and secular spaces. All of these important implications become backgrounded in simplistic approaches such as Riesebrodt's, which I understand to be the general assumption of our society. It should be the role of the public school from within the secular landscape to curb the temptation to rush to simplistic definitions and understandings by criticizing prevailing assumptions.

Knowing is temptation, albeit in a somewhat more singular sense than believed when referring habitually to the Evil Genius or to some original sin. The temptation of knowing, the temptation of knowledge, is to believe not only that one knows what one knows (which wouldn't be too serious), but also that one knows what knowledge is, that is, free, structurally, of belief or of faith - of the fiduciary or of trustworthiness. $^{85}$

The previous statement by Derrida accuses any epistemology as relying on faith, and is a highly problematic statement because consequentially it accuses all Western institutions as being inherently religious. The study of religion should provide citizens with the analytical mechanisms to renegotiate and redefine the nature of their religious inheritance.

\footnotetext{
${ }^{84}$ Ibid, pg. 29 - 30

${ }^{85} \mathrm{Ibid}$, pg. $30-31$
} 
Because it is not certain that in addition to or in face of the most spectacular and most barbarous crimes of certain 'fundamentalisms'..., other over-armed forces are not also leading 'wars of religion', albeit unavowed. Wars or military 'interventions', led by the Judaeo-Christian West in the name of the best causes (of international law, democracy, the sovereignty of peoples, of nations or of states, even of humanitarian imperatives), are they not also, from a certain side, wars of religion? ${ }^{86}$

The next and final chapter will now continue analyzing the violence created by a rigid and unreflective secular/religious divide, and suggest at least five ways in which the academic study of religion ameliorates such violence.

\section{CHAPTER THREE}

\section{INTRODUCTION}

The previous chapter explored the important relationship between the messianic aspects of language, which is language's implicit need to verify itself as accurately as possible in representing what it is referring to. I also explored the process by which the peripheral pole is formed, leads to understanding the humiliating experience of those on the periphery of a hegemonic centric discourse. The messianic element within language structures the platform from which individuals view and make sense of the world. That is, as people try to verify whatever it is they are talking about, the "whats" and the "whys," and the answers and newly articulated questions that arises from those answers, the very process of verification affects their worldview as well as their understanding of their environment. Their justifications are constructed along the binary mode illustrated in the previous chapter. Also explored in the previous chapter was the fact that justifications for binary language constructs operate in both our secular American culture as well as in the cultures that produce the religious terrorists. The chapter ended with considering

\footnotetext{
${ }^{86}$ Ibid, pg. 25
} 
American society as the center of the hegemonic discourse, and offering an example of the type of binary language constructs used to formulate a hegemonic centric discourse. The best way to rupture the association of America as this "evil center" is by criticizing the assumptions acted upon by Americans, which perpetuate and validate the humiliation of those on the periphery. I argue that some form of religious studies is best suited to provide the place and structure for such a critical analysis.

Michel Foucault has argued that "Education may well be, as of right, the instrument whereby every individual, in a society like our own, have access to any kind of discourse." ${ }^{\prime 77}$ The exclusion of the teaching about religion within the American public school system, and I am not referring to the optional elective in the select high schools that offer them, but the extensive teaching about religion as its own discipline, keeps the discussion about religion backgrounded from the discourse in other disciplines, since students and teachers lack the adequate skills to tease them out appropriately. Also, the backgrounding of the study of religion maintains the uncritical assumption of the doctrine of separation between religion as concerned with the metaphysical, and the secular as concerned with the affairs of this world. As if religion does not have something to say about each and every academic discipline, or as if the secular never resorts to ideology to define itself. Foucault comments on the temporality and discursiveness of such doctrines of separation, which should leave one wary of leaving them uncriticized.

But conversely, doctrine involves the utterances of speakers in the sense that doctrine is, permanently, the sign, the manifestation and the instrument of a prior adherence...to a struggle, a revolt, resistance, or

\footnotetext{
${ }^{87}$ Foucault 1976, pg. 227
} 
acceptance. Doctrine links individuals to certain types of utterances while consequently barring them from all others. ${ }^{88}$

As the doctrine of separation between religion and the secular has a particular history and rationale here in the United States, when immigrants come from other cultures, especially non-European ones, or American soldiers are sent to other cultures, the particular rationale for the doctrine of separation, with its particular struggles, revolts, resistances, etc., do not effect and therefore do not reflect the reality of other notions of religion and the secular. To not respect other understandings of the secular and religious is problematic when considering the process of globalization, especially in its hegemonic centric form as discussed by Plumwood that silences the voices of opposition to globalization. According to Diane Moore, the public school system ought to fulfill the mission ascribed to it by Foucault and allow reflection on religious discourse within the public school system. Leaving aside the question of how to teach this in a public school, I do argue along with Moore that religious studies education is crucial to the healthy functioning of an informed citizenry. Criticizing social values would give citizens a greater sense of ownership of the values which are attributed to America, and enable them to better articulate rebuttals for those practices which certain Americans may not wish to support. The teaching about religion is also instrumental in transgressing the "bourgeois hegemony" bell hooks sees in the values pervading society. "Feminist and critical pedagogy are two alternative paradigms for teaching which have really emphasized the issue of coming to voice." ${ }^{89}$ Critique of social values is integral to my thesis about education, which will be discussed below.

\footnotetext{
${ }^{88}$ Ibid, pg. 226

${ }^{89}$ Hooks, pg. 181
} 
One assumption derived from religion to be analyzed below is that of anthropocentrism, or "human-centeredness." It is near ubiquitous among the world's religions and is rampant within our consumer capitalist society. Anthropocentrism in its most hegemonic form denies agency, intrinsic value, and voice to the environment, and this will be analyzed in detail below. All hegemonic centric discourses, are a form of anthropocentrism in the sense that the periphery is always denied agency, intrinsic value, and voice. The critique of anthropocentrism-operating from the process of defining human / non-human in a binary fashion as mentioned above — could then be extrapolated to critique other forms of hegemonic discourses. Bryan Norton describes the Western intellectual history of anthropocentrism and its biblical origin well. He writes:

At one important juncture in this intellectual history - when the JudeoChristian Creation story was written down - scriptures accorded humans 'dominion' over nature, but with the obligation of stewardship...Clearly, within the Western perspective, emphasis has often fallen on the 'dominion' and power aspect of the charge from Genesis. ${ }^{90}$

Anthropocentrism will be shown to be neither a universal given nor a prudent concept. By defining the environment against human needs, anthropocentrism obstructs love, awe, and respect for the environment on the environment's own terms, even when human and environmental interests converge. "So even if anthropocentrism doesn't change what we think it makes sense to do in the world, it might well change how we think it makes sense to feel about the world." ${ }^{.91}$ Such anthropocentrism is, I argue, smuggled into the "secular" from religious origins and only supports the need for religious studies as part of a balanced education.

\footnotetext{
${ }^{90}$ Norton, pg. $50-51$

${ }^{91}$ McShane, pg. 177
} 
This chapter will argue that religious studies is important in a "secular" society for at least five reasons: 1) to equip citizens with the skills necessary to consciously deliberate and criticize the values and ideals they are reproducing, 2) to develop a varied understanding of agency and respect for its consequences, 3) to establish a common place for social critique, 4) to prepare citizens for a functional role in the economy of society, and 5) and to provide citizens with the tools necessary to articulate and practice their own sense of a fulfilling life. The exclusion of teaching about religion from public life handicaps people because it ignores an extremely influential and important dimension of the human experience and its effects on society throughout time and space. Religious literacy would fulfill the above aims through the following four effects: 1) by providing another analytical lens with which to critique society, 2) by providing the necessary tools for a comprehensive understanding of the dynamic actors structuring society, 3) by giving alternative models of agency, and 4) in a globalizing world, religious literacy is necessary for the social cohesion necessary to enable a fulfilling life. Moreover, religious illiteracy has three negative effects which will be explored below, it: 1) constructs a worldview which implies that religion, a whole family of worldviews, is, at best, not essential, and at worst, "backward or despotic," 2) leaves religiously based assumptions operating uncritically within society in place, and 3) closes opportunities for viewing alternative models of organization, encumbering social criticism. Moreover, the term "religion" itself becomes uncritically defined against whatever the normative American experience of religion is at the immediate expense of some other definition of religion more sensitive to other conceptualizations of the term. These ideas are drawn from the educational philosophies of Diane Moore, John Dewey, bell hooks, and Elizabeth 
Schussler-Fiorenza, all of whom advocate the importance of the connection between an articulate citizenry and an egalitarian democracy. The teaching about religion is instrumental in transgressing the "bourgeois hegemony" bell hooks sees in the values pervading society.

Feminist and critical pedagogy...have really emphasized the issue of coming to voice. That focus emerged as central, precisely because it was so evident that race, sex, and class privilege empower some students more than others, granting 'authority' to some voices more than others. ${ }^{92}$

\section{RELIGIOUS ILLITERACY}

Religious literacy is important first of all because the discourses of our modern secular society are rooted in previous religious discourses. To fully enabled citizens to deliberate intelligently on social issues within our democracy, religious literacy is paramount. Moore discusses this very point. She writes, "I was very explicit about the need for citizens to have better tools to understand the role of religion in society so that they can help strengthen public discourse around contentious issues from a more informed position." ${ }^{.93}$ Elizabeth Schussler-Fiorenza has argued for a similar position regarding the teaching about religion. She writes, "We need to learn how to produce and teach knowledge of the biblical text not simply for knowledge's sake or for some mediating understanding, but rather also for engaging the intersectional analytic of kyriarchy and kyriocentrism, for the sake of conscientization and critical knowledge

\footnotetext{
92 hooks, pg. 185

${ }^{93}$ Moore, pg. 116
} 
production." ${ }^{94}$ The term kyriarchy is derived from a compounding of two Greek words; kurios - meaning lord, or ruler, and arkheion, which was discussed at length in the previous chapter. When these two terms are compounded together, as Schussler-Fiorenza does, it connotes a sense of an exclusive lordship over access to the archive, both to their topographical construction, the "having a place," and the conditions which govern their temporal occurrences. Access to these archives has historically been controlled by men, along with their proper implementation: hence "patriarchy". Schussler-Fiorenza's understanding of the kyriarchy is congruent with the "modern project" already discussed throughout the thesis, so the "modern project" could be understood as kyriarchal. Religious literacy is an important skill to promote within a democracy because of the politics of differentiation within a democracy that kyriocentrism and kyriarchy play on, through binary language, to formulate hierarchies of exploitation. Kyriocentrism and kyriarchy negatively affect the social cohesion of a society because it depends on binary language and the backgrounding of the other. Both Moore and Schussler-Fiorenza articulate the relationship between social cohesion, religious literacy, and an egalitarian democracy. Moore emphasizes the need for religious literacy for issues of social cohesion and peace. "If we fail to educate today's children with the skills to participate in and advance democratic citizenship that is defined as a political as opposed to an economic category, then the democracy that we Americans so cherish will inevitably erode into an empty shell of slogans without substance." ${ }^{.95}$ Not only is social cohesion affected by religious illiteracy, but also the structure of democracy can become affected when discourse on religion is silenced. Moore's three manifestations of religious

\footnotetext{
${ }^{94}$ Schussler-Fiorenza, pg. 118

${ }^{95}$ Moore, pg. 178
} 
illiteracy will be interlaced below with pertinent aspects of Schussler-Fiorenza's work on kyriarchy to demonstrate one possible consequence of religious illiteracy, the backgrounding of anthropocentrism within Western consciousness, which underscores the importance of religious literacy to democracy.

In Overcoming Religious Illiteracy Diane Moore has articulated three manifestations of religious illiteracy that are both worrisome and correctible. The first manifestation is when secularists dismiss religious convictions as unsophisticated and irrational. Moore cites an example from her own teaching experience, "Here it was revealed that four of the ten members of the class believed that religion itself represents worldviews that they characterized as 'unsophisticated, irrational, and oppressive.' They classified themselves (in direct contrast) as 'secular humanists' (read sophisticated, rational, and non-oppressive) and implied that 'all intelligent' people share this selfdefinition." ${ }^{96}$ Jeff Schweitzer wrote an article that has been posted on Richard Dawkins' website which betrays this same bias.

So, why religion? Human weakness and gullibility. The master of all major faiths is the compelling quintet of fear of death, the need to explain away the unknowns of nature's mystery, hopes for controlling one's destiny, a desire for social cohesion, and the corrupting allure of power. Nowhere in that equation is the assumption that life has purpose and meaning. Instead, the religion we created demands that life have purpose, one that can be found only through faith, as a means of selfjustification, and since we believe in our own creation we do not question the conclusion. ${ }^{97}$

The analysis reduces the different dimensions of religion to revolve around the phenomenon of the fear of death and self-preservation, with the power to manipulate this

\footnotetext{
${ }^{96}$ Moore, pg. 36

${ }^{97}$ Schweitzer, http://richarddawkins.net/articles/505248-the-end-of-religion
} 
fear by religious authorities with no good justification. While his analysis may not be completely false, it does obscure the experiential dimension of religion which focuses on a particular experience that an individual has self-described as religious in nature. Also, it assumes that secularists have no fear of death whatsoever, which seems doubtful given the emphasis to the biological sciences to extend individual human life as long as possible. And is such an emphasis not also a hope of controlling one's destiny? And of course, the secular state does have many coercive ways of maintaining social cohesion.

Such an insulting portrayal of religion is a manifestation of religious illiteracy, because it suggests that religion and religious people are the only ones acting on faith, and only on faith. The implicit referral to religion as concerned only with "faith," "the metaphysical," etc. as a manifestation is even more problematic when broadened by the inclusion not only of secular polemics against religious worldviews into the analysis, but of polemics from religious peoples against other religious worldviews, which trickles into one religion telling another religion how to practice religion. The exclusion of the teaching about religion, not only its historical and cultural importance but as its own discipline, understanding religion from its own perspective, perpetuates religious illiteracy as perceiving religion as "unimportant" or "unconcerned" with the world. Moreover the dismissal of religious worldviews backgrounds their influence on modern secular discourse, which in this paradigm is seen as solely concerned with the world. "Since modern liberal democracies are modeled after the classical ideal of kyriarchal democracy, they continue the contradiction between kyriarchal practices and democratic self-understandings inscribed in the discourses of democracy in antiquity." 98 The

\footnotetext{
${ }^{98}$ Schussler-Fiorenza, pg. 117
} 
backgrounding of the discourse on religion, and its relegation to the periphery, occludes the functioning of the first two structures of Schussler-Fiorenza's kyriarchy. The first structure states that a kyriarchy is an exploitative hierarchy that "must not be seen as static but as an always changing net of relations of domination." Static approaches to religion, such as Riesebrodt's discussed in the first chapter, blinds the analyst in viewing how the periphery is constructed in relation to the center and religion's place(s) within them. The fluidity of kyriarchy underwrites the second structure which argues that "Kyriarchy is realized differently in different historical contexts... it is different in Greece, Hellenism, Rome, Asia Minor, Europe, America, Japan, or India; it is different in Judaism, Islam, or Catholicism.."99 Religious literacy is crucial for teasing out the manifestation of kyriarchies in other societies, which is also essential in unmasking our own kyriarchal structures. Moreover, the method through which we resolve kyriachial relations in our culture will not necessarily translate over in others. Such attempts include the drive to "unveil" Muslim women, or the call to completely eradicate female circumcision in all its contexts.

The second manifestation of religious illiteracy according to Moore is when religion is used to exclude groups of people from full participation within society by "defining the terms of the debates themselves." 100 The lack of tools, or of the prerequisite understanding to implement them, is a direct consequence of the exclusion and backgrounding by kyriarchal social systems and is further entrenched when the discourse on religion is silenced from such places as the public school. The example she

\footnotetext{
${ }^{99}$ Ibid, pg. 115

${ }^{100}$ Moore, pg. 38
} 
cites regards the efforts of groups such as the Alliance Defense Fund (ADF) and the Southern Baptist Convention (SBC) to exclude homosexuals from such activities as the Saint Patrick's Day Parade in Boston, and the exclusion of homosexuals as troop leaders from the Boys Scouts, describing how all of their actions are coded in religious language. ${ }^{101}$ Moore highlights more troubling actions perpetrated and supported by these two organizations, such as protests at rallies which

highlight the plight of gay, lesbian, bisexual, and transgendered (GLBT) youth who are often 'silenced' due to overt and covert forms of discrimination in the schools...One [participant in the protest] was at a public high school in a Boston suburb where parents and students gathered at the entrance to the school on the day of the protest with buttons and banners featuring the silhouette of a man and a woman holding and with the caption 'The Way it is Meant to Be. ${ }^{102}$

These positions however rely upon a particular hermeneutic which Moore argues are sectarian. "First, the arguments in support of these restrictions are theologically based upon particular sectarian perspectives...A number of religious groups and individuals have articulated religiously inspired moral arguments that are in direct contradiction to the positions represented above." ${ }^{103}$ The debate in the culture wars surrounding GLBT issues blurs the distinction between religion as a private matter, accomplished by barring GLBT people from the full privileges of citizenship through arbitrary and religiously grounded reasons through very the secular government which claims to be completely separated from religion. This manifestation could also be applied to other arbitrary restrictions on lifestyle behaviors that have a fundamental

\footnotetext{
${ }^{101}$ Ibid, pg. $38-47$

102 Ibid, pg. 41

103 Ibid, pg. 44
} 
religious assumption as the basis for their rational, such as temperance laws and their relation to the work ethic for example, or abortion.

Another example of the problematic distinction of religious vs. secular spaces in discourse is the recent controversy surrounding the proposed Park 51 Community Center, its association as an Islamic center, and the efforts of exclusion by various interest groups who cited a perceived loss of dignity to the memory of the victims of 9-11. The discourse surrounding "Park 51" belies many "isms" about American Muslim communities that are built upon hierarchies of exclusion. Muslim's in the US have become a particular site of fear for those at the center of hegemonic discourse. The popular politico Glenn Beck perpetuates this misunderstanding and fear on his website which hosts articles that deliberately misrepresent Muslims and Shari'a law as unreasonable. Frank Wuco's characterization of Shari'a law, who is the author of the article on Glenn Beck's website states:

So, from these two sources, the Qur'an and the Hadith, are drawn the instructions and prescriptions for all facets of life, conduct, and law, for both individuals and the community as a whole in Islam. To the Muslim, having been drawn from the Qur'an (the direct, undiluted "Word of God") and the Hadith (the customs, habits, and sayings of God's final prophet, Muhammad, the most perfect man ever created), shari'ah is the law of God (Allah), delivered to all of humanity 1,400 years ago! ${ }^{104}$

Then Frank Wuco presents Muslims as unreasonable, despite the fact that he

could be making the same argument that American nationalists do for the United States.

When his brothers and sisters in jihad kill in defense of Islam and shari'ah, their victims have not only gotten what they deserved, by the will of God, they will then suffer an eternity of pain unimaginable in

${ }^{104}$ http://www.glennbeck.com/content/articles/article/198/47676/, accessed 01/03/2011 
hellfire. To Shazad, his sufferings in the Supermax Federal Prison in Colorado will be only temporary and rewarded with an eternity of delight and pleasure in heaven. Such is the belief system that proponents of shari'ah desire to see spread the world over, America being no exception. ${ }^{105}$

The third manifestation of religious illiteracy according to Moore is when sectarian perspectives are normalized. She cites the examples of intelligent design as biological science and the efforts of certain groups at reintroducing Biblical studies as "Bible as history" within the classroom. Moore argues to teach these topics as presented would be teaching religion as opposed to teaching about religion because a sectarian perspective is necessary for them to be taught as such. Moore is also sensitive to the fact that a sectarian perspective is necessary for them to be excluded in the first place. Moore offers a compromise,

Though teaching creationism and intelligent design in biology classes as alternative 'scientific' theories to evolution are examples of teaching religion...teaching about these perspectives...on understanding the culture wars would be very appropriate...Similarly, it would be appropriate to teach a course... that focused on the comparative methods of Biblical interpretation...In this way, Biblical literalism would be presented as one method among many, rather than as the only foundation for exploration. ${ }^{106}$

The uncritical normalization of sectarian perspectives can only be witnessed to if there is a level of religious literacy within society, which is highly likely when a binary is created between the religious/private, secular/public. The smaller the circle of religiously literate people, the more difficult it becomes to convince the religiously illiterate of the operation of their backgrounded religious assumptions. The greater the spread of religious illiteracy then the intelligibility of the secular as the non-religious becomes

\footnotetext{
105 Ibid

${ }^{106}$ Moore, pg. 52
} 
more opaque as the secular is presented to another religion. The normalization of sectarian views is the most serious and most difficult manifestation to confront and serves as the basis that reinforces the previous two manifestations, when religion is used to exclude groups from full participation in society, and when sectarian perspectives are normalized within the curriculum. The normalization of sectarian views is what normalizes the exploitive relationships within a kyriarchy. The process of normalization is the seventh structure of Schussler-Fiorenza's concept of kyriarchy:

The contradiction between the logic of democracy and historical sociopolitical kyriarchal practices has produced the kyriocentric (mastercentered) logic of identity as the assertion of 'natural differences' between elite men and wo/men, freeborn and slaves, property owners and farmers or artisans, Athenian-born citizens and other residents, Greeks and barbarians, the civilized and uncivilized world. ${ }^{107}$

It is this normalizing process that my critique seeks to rupture, and this critique depends upon access to multiple discourses on religion.

\section{REASONS FOR RELIGIOUS STUDIES}

The five purposes for religious studies education noted above in the introduction are drawn principally from Diane Moore's three purposes for education in Overcoming Religious Illiteracy. Her work, focusing on teaching about religion in the public schools, will be considered here as a point of departure for discussion, and her purposes are: "1) to function as active citizens who promote the ideals of democracy; 2) to act as thoughtful and informed moral agents; and 3) to lead fulfilling lives." ${ }^{\text {,108 }}$ My aim here parallels Moore's but with some differences. Both emphasize that the purpose of education is to instill awareness within the student that there is a doing, a practice, necessary to

\footnotetext{
${ }^{107}$ Schussler-Fiorenza, pg. 116

${ }^{108}$ Moore, pg. 9
} 
functioning as an active citizen within a democracy, and that this practice is the living out of democratic ideals. The nuanced difference between Moore's first purpose and my own is that I emphasize the importance self-criticism of one's practice because every practice has effects one does not intend. Also, I explicitly argue that religious studies education should concentrate on promoting deliberation and criticism to emphasize that students are active in the reproduction of values that are taught and practiced. Though Moore discusses deliberation and criticism in her work as assumptive to democratic values, deliberation and criticism are not always necessarily democratic values. Therefore, this study finds that it should not be assumed as a democratic value and is explicitly stated as a purpose of education. Moore does illustrate several other values that a democracy should embody and they are worth considering. Moore quotes Webster's Dictionary's entry for "democracy" to articulate her own understanding of the essential democratic values a public school should foster within students. They include respect and tolerance: 1) for minorities, 2) an individual's freedom of expression, 3) for individuals to develop to their fullest human capacities, and 4) of the equal worth and dignity of each individual,. ${ }^{109}$ Each of these four points is wrought with contention, which grounds the imperative for them to be discussed within the public school. Moore comments, "It is instructive, for example, to understand how the founding fathers could wholeheartedly affirm the values put forth in the Declaration of Independence while at the same time justify the ownership of human beings as slaves. In a more contemporary example, how 'democratic values' are defined is hotly contested in the current culture wars." ${ }^{\text {110 }}$ Both of Moore's examples can only be critically engaged and understood with a sufficient

\footnotetext{
${ }^{109}$ Ibid, pg. 10

${ }^{110}$ Ibid
} 
religious literacy to give a comprehensive understanding of their underlying processes. The first example, slavery provides an example on how hermeneutical conflicts were used to justify both the institution of slavery and its abolition. This serves to explain how the Founding Fathers could affirm both the humanistic language of the Declaration of Independence, while at the same time affirm to slavery's implementation in the Constitution. This is an important phenomenon of the American past, and to background religion's involvement in the debate surrounding slavery in the United States serves to occlude Moore's second point about how "democratic values" are constructed. This is a powerful reason for the inclusion of the study of religion as its own subject.

Moore's second purpose of education, "to act as thoughtful moral agents," also influences my second purpose stated in the introduction. Moore's second purpose of education logically follows and reinforces her first purpose of education, which is for students to become functional in promoting the ideals of democracy. It is through the agency embedded within students and the educational system that social values are reproduced and continue to exist. Education then should make students aware of the relationship between the consequences of practice against the rest of the environment, democracy being the political environment of the United States. Agency and practice, including the agency of the school and of the students, is what reproduces society. That is, for democracies to reflect the values articulated in the above paragraph, it is only by 'being' democratic and acting upon democratic principles that democracy can continue. Moore reiterates this rationale for her second purpose arguing that "Schools should inspire and empower students to take themselves seriously as moral agents capable of 
making a positive difference in the world." "111 This chapter broadens Moore's second purpose by emphasizing not only the student's role as an agent, but in education's purpose to cultivate a sense of moral agency within the student, the "why" to or not to act. I argue that the school is an agent in itself, albeit a social agent rather than an individual. Education can thereby criticize the prevailing assumption of agency as an individual and active phenomenon. Plumwood has characterized the extreme example of the effect when the assumed concept of individual agency is left unchecked and perceived as the only form of agency possible. Individual agency cannot remain as a static uncharacterized concept, it needs to be attached to an object to make sense, this object has traditionally been the male landowner who "picked himself up by his bootstraps," through the use of reason. "The self-made man is for the most part a hyperseparated autonomous self whose illusion of self-containment is built on denying or backgrounding the contributions of subordinated others and re-presenting the joint product in terms of a hyperbolised individualistic agency who is to be treated as the only or primary 'achiever.",112 Students are rarely instructed on other forms of agency, such as individual and passive, social and active, or social and passive. Likewise, they are not given the tools to criticize the patriarchal background on which our conceptualization of agency is grounded. Plumwood further articulates how the backgrounding of the complexity of agency leads to the assumption of humans being somehow separated from the natural environment, which is seen as inert or "mechanical." Exclusion serves as the true base for kyriarchal exploitation as the first backgrounded other, upon which all of the other kyriarchal qualifications are based to support the kyriarchal pyramid. The

\footnotetext{
${ }^{111}$ Ibid, pg. 16

${ }^{112}$ Plumwood, pg. 27
} 
separating of human beings from the natural environment leads to binary construction. "Such systems conspire to conceal from us our dependency on nature, to overestimate our autonomy and manipulative ability...According to its story, nature has no agency or autonomy of its own and imposes no real limits on us." ${ }^{113}$ The discourse on individual agency and the discourse to background other forms of agency have their roots within religious discourses from our European-Christian past and its criticism is contingent upon fostering a critical discourse around religion.

For education to fulfill the previous two of Moore's purposes however, Moore recognizes that the public school system would need to fulfill the mission of making every discourse available to the student as ascribed to it by Foucault. To enable this means allowing religious discourse to enter into the public school system. Allowing access to as many discourses as possible is what allows the public school to act as a space for social critique and evaluation of discourses, in order to bring to light and question such assumptions as the clear differentiation between religion and the secular. This understanding of the public school builds on the notion of the space of education as a critical space, emphasizes its location in community. The third purpose of education I articulated above attempts to build this understanding into the space of public schools. Uncritical social assumptions, such the doctrine of a clear differentiation between religion and the secular, should be publically challenged since they are based on a particular discourse and history. These formations concerning the roles between the school, society, and religion, have been described by Schussler-Fiorenza as a hermeneutical "dance," each dependent on the other and on a shared Christian heritage. Schussler-

\footnotetext{
${ }^{113}$ Ibid, pg. 35
} 
Fiorenza elaborates on the relationship between the various 'dance' partners. She writes, "Thus the dance of interpretation always has as its goal a hermeneutics of change and transformation. When seeking future visions and transformations, we can only extrapolate from present-day experience, which is always determined by past experience." ${ }^{, 14}$ Since education seeks to critique and transform society, education should look towards other religion to seek examples that break the hold particular Christian interpretations have on concepts such as agency. Schussler-Fiorenza argues:

The spiraling dance of interpretation seeks to engender public the*logical deliberation and religious transformation. It is not restricted to Christian canonical texts, but it can be and has been explored successfully by scholars of other religious traditions. ${ }^{115}$

The previous articulation third purpose of education may seem redundant since the first purpose explicitly states criticism as a democratic value and Moore articulates critical thinking skills as integral to moral agency and the reproduction of social values. "Students should be encouraged to foster this optimism and the critical thinking skills necessary to recognize and interrogate contemporary social values and assumptions to ensure that the values promoted are consistent with those they consciously wish to promote." 116 However, there has been a running assumption throughout this thesis that education takes place in a school. Thus, my third purpose verbalizes the school as the site of education and nuances it by highlighting the actual place of the school as a site of critique. Also, by correlating social critique with education I reinforce their relationship so that social critique is education and to educate means to be critical. Finally, by

\footnotetext{
${ }^{114}$ Schussler-Fiorenza, pg. 124

115 Ibid, pg. 125

${ }^{116}$ Moore, pg. 21
} 
establishing the place of the school within the community, I argue for the contextualization of the relationship between the curriculum and social critique in general to the needs of the local community and the society at large. Finally, I reinforce with this third purpose, what Schussler-Fiorenza means by "ethos." Drawing on the work done by Susan Jarratt and Nedra Reynolds, Schussler-Fiorenza ties the etymology of the word "ethos" to both ethos and ethea. She writes, ethos is not only tied to "the Greek ethosmeaning custom, habit, usage, folkways- or from the Greek èthos- meaning character formation as the totality of all characteristic traits rather than mere custom or morally approved habits."117 But it is also tied to the Greek term èthea, which is, "a plural noun that is the original root of both terms and means 'hunts' or 'hangouts.' This etymology understands ethos as a pedagogical space where customs and character are formed." ${ }^{118}$ The understanding of pedagogy as a "hunt" retains the notion that education is found on the margins and is a form of labor, as well as being congruent with our dual notions of place in respect to the archive. The "hunts" inevitably took place, remember the "taking place of an archive," within a wilderness as the "having a place," where this ethics were formulated, and has the sequential implication of providing nourishment for the exercise. The "hangouts," a "having a place" of the archive, emphasizes the place of the public school as a social space for construction students with the practical skills to obtain employment. "Ethos as a disciplinary space determines the professional character of individuals...In this spatial sense, ethos theorizes the 'positionality' inherent in rhetoric." "119 The objective of this chapter's third purpose of education is to verbalize the

${ }^{117}$ Schussler-Fiorenza, pg. 163

${ }^{118}$ Ibid

${ }^{119}$ Ibid, pg. $163-164$ 
relationship between the environment, the school, education, and the student as a critical relationship.

The overcoming of religious illiteracy has an economic component to it which is articulated in my fourth purpose of education mentioned in the introduction, viz. that education should prepare students for a functional role in the economy. There are two dimensions to religious literacy which affect the economy. First, the present service economy requires sensitivity to differing worldviews. The second but co-dependent dimension to religious literacy is the element of social cohesion necessary for a stable economy in general. Education itself has a greater role than simply literacy. John Dewey in Democracy and Education has argued that education has a vocational aspect. He writes, "Nothing is more tragic than failure to discover one's true business in life, or to find that one has drifted or been forced by circumstance into an uncongenial calling...Plato laid down the fundamental principle of a philosophy of education when he asserted that it was the business of education to discover what each person is good for." ${ }^{120}$ Circumstances of course dictate the type of jobs which citizens will be able to hold and the United States in the last twenty years has steadily become a service economy rather than a manufacturing or agricultural economy. As a service economy, interpersonal skills are extremely important and religious literacy is an important interpersonal skill to have. However, education should also be critical of economic theories and practices which exacerbate the myth of human separation from the natural environment. A society highly reliant on a service economy is prone to reinforce this myth as if we don't daily depend upon the rest of the natural world. "This is exemplified

\footnotetext{
${ }^{120}$ Dewey, pg. 167
} 
in the recent hype about the 'weightless' economy, which comes very close to denying the necessity of the material world. ${ }^{, 121}$ Finally, religious literacy would contribute to vocation discernment that Dewey calls for. An occupation is fundamental to living a fulfilling life, which is the last of the purposes of education this paper is considering.

Ultimately, the previous four purposes lead to the cultivation of a purposeful, fulfilling, and contributive life, and for this reason, Moore argues, the school curriculum should be as broad as possible. "Literacy of all kinds (numeric, artistic, scientific, religious, linguistic, cultural) should be consistently promoted and evaluated in ways that are meaningful and relevant." ${ }^{122}$ Religious literacy is the focus of this study and it is seen as crucial for this last purpose because religious literacy allows students to critique and transform society. For many who are living on the bottom of the kyriarchal pyramid, leading a fulfilling life means transgressing those very assumptions which have maintained such structures of domination. bell hooks comments on how a transgressive pedagogy creates a sense of excitement in students by reflecting on her first experience in a desegregated school.

When we entered racist, desegregated, white schools we left a world where teachers believed that to educate black children rightly would require a political commitment. Now, we were mainly taught by white teachers whose lessons reinforced racist stereotypes. For black children, education was no longer about the practice of freedom. Realizing this, I lost my love of school. ${ }^{123}$

One important assumption which could easily be problematized with the inclusion of the study about religion with the public school is that of anthropocentrism. The next

\footnotetext{
${ }^{121}$ Plumwood, pg 97

${ }^{122}$ Moore, pg. 23

123 hooks, pg. 3
} 
section will provide a detailed discussion on anthropocentrism, why it is a cultural construct, and why it is important to criticize it.

\section{CONCLUSION}

The thesis has taken a deconstructive, discursive view of the different elements necessary for maintaining a "divide" between the "secular" and the "religious." Such a divide, I have argued, is itself encapsulated in a particular religion's history. I introduced Derrida's concept of the archive and messianism to elaborate on how these binary divisions are formed, understood, and reproduced, and pointed to their intended and unintended consequences. The promulgation of such a divide engenders a potential to violence because of the unbounded varieties of what religion can represent. The reproduction of this divide is archived, both socially and individually, with all of the violent and non-violent episodes and experiences providing its content. Without accessing these various archives, they cannot be critiqued, and their operative agency within the framework of society goes unchecked and left free to run abound. These effects were analyzed using Derrida's concepts of messianism, chora, and archive, which highlighted how important it is to care for the archive through criticism, to rupture misrepresentations and to highlight the co-dependence of concepts. A critical space is necessary to rupture problematic binaries and provide citizens with the tool of religious literacy. About space, the teaching about religion in public schools also provides a place within the secular landscape for religions to voice themselves, and for secular spaces to coherently define themselves as the other space. The facilitation of a multivocal discourse is the primary reason for including the teaching about religion in public 
schools, since such spaces are discursively formed and therefore discourse between both spaces is necessary for them to be intelligible.

The increased sensitivity to religion has ramifications, not only for our own society, but also for the other cultures we necessarily deal with. By viewing just how the local environment warps and changes what it means to have a religious space or a secular space, it hopefully emphasizes a concern for the care and value of differing religious environments and traditions. Moreover, awareness of the religious environment brings to light our own religious assumptions so we can qualify and critique them. Sensitivity to the religious environment gives students a deeper understanding of other societies from within their own perspectives, as well as a clearer understanding of the ramifications of our own actions upon them, most powerfully seen through the present process of globalization and the violent responses by some of its discontents. The level of sensitivity to a religious environment is contingent upon the level of religious literacy in society. The relationship between the two generates the second reason for incorporating the study about religion, which is to develop the tool of religious literacy in the first place. Religious literacy is the bridge between the first reason, to maintain an open discourse, and the third reason, that uncriticized assumptions are locally and environmentally constructed, and when transported to another environment, i.e. culture, they engender violence when applied without sophistication or caring. If the consequences of religious illiteracy were benign, then the problem would not be so serious; however, the continued pervasiveness of religious cultures of violence, demands that they be addressed. 


\section{BIBLIOGRAPHY}

Asad, Talal. Genealogies of Religion: Discipline and Reasons of Power in Christianity and Islam. The John Hopkins University Press. Baltimore, MD. 1993.

Asad, Talal, Formations of the Secular: Christianity, Islam, and Modernity. Stanford University Press. Stanford, CA. 2003.

Berkman, Wilfred and Joanna Pase. "In Defense of Anthropocentrism." Environmental Ethics: The Big Questions, D. Keller ed., Wiley-Blackwell, Chichester, U.K., 2010, pgs. 83-88.

Chafets, Zev. "The Power of 50: Our First Annual Ranking of America's Highest Paid Pundits and Politicos." Newsweek, November 8, 2010, 32 - 36.

Derrida, Jacques. "Faith and Knowledge: The Two Sources of 'Religion' at the Limits of Reason Alone." Religion. Ed. Derrida and Gianni Vattimo, Stanford University Press, Stanford, CA, 1996.

Derrida, Jacques. Archive Fever: A Freudian Impression. University of Chicago Press. Chicago, IL. 1998.

Dewey, John, Democracy and Education, Feather Trail Press, U.S.A. 2009.

Foucault, Michel. The Archeology of Knowledge and the Discourse on Language. Trans. A. M. Sheridan Smith. Vintage Books, New York, NY. 1972.

Foucault, Michel. The Foucault Reader. Ed. Peter Rainbow. Vintage Books. New York, NY. 2010.

Foucault, Michel. The Essential Foucault. Ed. Peter Rainbow and Nikolas Rose. The New Press. New York, NY. 2003.

Fenn, Richard K. Time Exposure: The Personal Experience of Time in Secular Societies. Oxford University Press. New York, NY. 2001.

Gibbs, Robert, "Messianic Epistemology," ed. Yvonne Sherwood and Kevin Hart, pg. 119 - 130. Routledge, London, U.K., 2005.

hooks, bell, Teaching to Transgress: Education as the Practice of Freedom, Routledge, New York, NY, 1994.

Juergensmeyer, Mark. Terror in the Mind of God: The Global Rise of Religious Violence. University of California Press, Berkeley, CA, 2003, $3^{\text {rd }}$ Edition.

Limbaugh, Rush. "Ground Zero Terrorist Recruitment Center Imam: Build Mosque or Else."

http://www.rushlimbaugh.com/home/daily/site 090910/content/01125110.guest.h tml, September 9, 2010. (accessed December 11, 2010) 
Limbaugh, Rush. "Islam: The Only Religion Protected and Defended by the American Left."

http://www.rushlimbaugh.com/home/daily/site 082510/content/01125110.guest.h $\underline{\text { tml }}$, August 25, 2010. (accessed December 11, 2010)

McShane, Katie. "Anthropocentrism vs. Non-Anthropocentrism: Why We Should Care." Environmental Values, Vol. 16, No. 2, May 2007, pgs. 169 - 185.

Medin, Douglas, Sandra Waxman, Jennie Woodring, and Karen Washinawatok. "Humancenteredness is not a universal feature of young children's reasoning: Culture and experience matter when reasoning about biological entities." Cognitive Development, Vol. 25, 2010, pgs. 197 - 207.

Moore, Diane L., Overcoming Religious Illiteracy: A Cultural Studies Approach to the Study of Religion in Secondary Education. Palgrave Macmillan, New York, NY, 2007.

Norton, Bryan G. "Why Study Environmental Ethics?" Environmental Ethics: The Big Questions, D. Keller ed., Wiley-Blackwell, Chichester, U.K., 2010, pgs.50 - 51.

Plumwood, Val. Environmental Culture: The Ecological Crisis of Reason. Routledge, London, U.K., 2002.

Rickert, Thomas. "Toward the Chora: Kristeva, Derrida, and Ulmer on Emplaced Invention." Philosophy and Rhetoric, Vol. 40, Num. 3, 2007, pgs. 251 - 273.

Riesebrodt, Martin. The Promise of Salvation: A Theory of Religion. Trans. Steven Rendall. The Chicago University Press. Chicago, IL. 2010.

Robert, William. "Witnessing the Archive: In Mourning." Religion, Violence, Memory, and Place. Ed. Oren Stier and J. Shawn Landres, pg. 37-51. Indiana University Press, Bloomington, IN, 2006.

Robinson, Richard H., Willard L. Johnson, Thanissaro Bhikkhu. Buddhist Religions: A Historical Introduction. Thomson and Wadsworth. Belmont, CA. 2005

Said, Edward W. Orientalism. Vintage Books, New York, NY, 1994.

Schweitzer, Jeff. “The End of Religion.” August 25, 2010. http://richarddawkins.net/articles/505248-the-end-of-religion (accessed on 01/03/2010)

Schussler-Fiorenza, Elisabeth. Democratizing Biblical Studies: Toward an Emancipatory Educational Space. Westminister John Knox Press, Louisville, KY, 2009.

Taylor, Bron. Dark Green Religion. University of California Press. Berkeley, CA. 2010. 
Wuco, Frank, "Shari'ah Law: What is Old is New."

http://www.glennbeck.com/content/articles/article/198/47676/, November 4, 2010 (accessed on 01/03/2011) 